\title{
Autoimmune and Rheumatic Manifestations Associated With COVID-19 in Adults: An Updated Systematic Review
}

\author{
Kuo-Tung Tang ${ }^{1,2,3}$, Bo-Chueh Hsu ${ }^{4}$ and Der-Yuan Chen ${ }^{5,6,7 *}$ \\ ${ }^{1}$ Division of Allergy, Immunology, and Rheumatology, Taichung Veterans General Hospital, Taichung, Taiwan, ${ }^{2}$ Faculty of \\ Medicine, National Yang-Ming University, Taipei, Taiwan, ${ }^{3}$ Ph.D. Program in Translational Medicine and Rong Hsing Research \\ Center for Translational Medicine, National Chung Hsing University, Taichung, Taiwan, ${ }^{4}$ Division of Allergy, Immunology and \\ Rheumatology, Taichung Veterans General Hospital Puli Branch, Nantou, Taiwan, ${ }^{5}$ Translational Medicine Laboratory, China \\ Medical University Hospital, Taichung, Taiwan, ${ }^{6}$ Rheumatology and Immunology Center, China Medical University Hospital, \\ Taichung, Taiwan, ${ }^{7}$ College of Medicine, China Medical University, Taichung, Taiwan
}

\section{OPEN ACCESS}

Edited by:

Pier Luigi Meroni,

Istituto Auxologico Italiano

(IRCCS), Italy

Reviewed by:

Tadej Avcin

University Medical Centre

Ljubljana, Slovenia

Janine Adele Lamb,

The University of Manchester,

United Kingdom

*Correspondence:

Der-Yuan Chen

dychen1957@gmail.com

Specialty section:

This article was submitted to Autoimmune and Autoinflammatory

Disorders,

a section of the journal

Frontiers in Immunology

Received: 22 December 2020

Accepted: 17 February 2021

Published: 12 March 2021

Citation:

Tang K-T, Hsu B-C and Chen D-Y (2021) Autoimmune and Rheumatic

Manifestations Associated With

COVID-19 in Adults: An Updated

Systematic Review.

Front. Immunol. 12:645013. doi: 10.3389/fimmu.2021.645013
Background: Numerous cases of the coronavirus disease 2019 (COVID-19) with autoimmune and rheumatic manifestations have been reported. Despite the available reviews that summarized its autoimmune/rheumatic manifestations, a systematic approach is still lacking. Therefore, we conducted a comprehensive systematic review in order to give an overview upon these rare but clinically significant manifestations.

Methods: We performed a literature search of PubMed and EMBASE as of October 9, 2020. All articles relevant to either systemic or organ-specific autoimmune and rheumatic manifestations potentially associated with COVID-19 were collected. The reviewed literature were limited to adults $\geq 18$ years.

Results: Although most of the existing evidence was based on case reports or case series without a long-term follow-up, a variety of autoimmune/rheumatic manifestations were associated with COVID-19. The manifestations that have a consistent association with COVID-19 include autoimmune cytopenia, cutaneous vasculitis, encephalitis, and Guillain-Barre syndrome. Such association is conflicting as regards to antiphospholipid syndrome, hemophagocytic lymphohistiocytosis, and myasthenia gravis.

Conclusion: Our systematic review indicated the potential of the COVID-19 virus to trigger a myriad of autoimmune and rheumatic manifestations, which should be considered amid global efforts to combat COVID-19.

Keywords: autoimmune disease, rheumatic disease, COVID-19, SARS-CoV-2, treatment

\section{INTRODUCTION}

Since the initial outbreak at Wuhan in December 2019, the coronavirus disease 2019 (COVID-19) pandemic has brought about a tremendous burden to the healthcare systems, and is still a huge threat to all human beings. As of 25th November 2020, nearly 60 million cases had been diagnosed, unfortunately with 1.4 million fatalities globally (1). Its manifestations ranged from asymptomatic infection, mild respiratory illness, acute respiratory distress syndrome (ARDS), and multiple organs failure. More and more reports regarding its associated autoimmune and rheumatic manifestations 
appeared as COVID-19 cases surged. These manifestations are noteworthy since they were either associated with increased morbidity, e.g., antiphospholipid antibody syndrome (APS), or life-threatening, e.g., multisystem inflammatory syndrome (MIS), as summarized in previous reviews $(2,3)$. Furthermore, one of the concerns about vaccination is its potential to cause similar autoimmune and rheumatic complications. With new reports accumulating at a rapid speed, we have undertaken a comprehensive systematic review and hoped it would help delineate the landscape of autoimmune and rheumatic manifestations associated with COVID-19.

\section{MATERIALS AND METHODS}

\section{Literature Search}

This systematic review focused on the autoimmune and rheumatic manifestations associated with COVID-19 infection. The algorithm of the systematic review follows the Preferred Reporting Items for Systematic Reviews and Meta-Analyses (PRISMA) checklist, as shown in Figure 1. Firstly, we searched the PubMed and EMBASE on October 9, 2020. The search strategy is illustrated in detail in Appendix 1 in Supplementary Material. The search keywords for systemic autoimmune diseases included systemic lupus erythematosus (SLE), spondyloarthropathy, and hemophagocytic lymphohistiocytosis
(HLH), etc.; those for organ-specific immune-related diseases included Guillain-Barré syndrome (GBS), uveitis, and interstitial lung disease (ILD), etc.

\section{Study Selection}

Three authors (KT Tang, BC Hsu, and DY Chen) independently assessed the titles and abstracts identified by the aforementioned search, and the relevant full-text articles were retrieved. Two authors (KT Tang and DY Chen) independently assessed the full-text articles for eligibility, resolved discrepancies through discussion or consultation with the third author (BC Hsu). The references for the selected articles were also examined for relevance. Articles were selected if they: (1) involved adults $\geq 18$ years; (2) were potentially relevant to autoimmune or rheumatic manifestations concurrent with or following COVID19 infection; (3) were potentially relevant to an exacerbation of pre-existing autoimmune or rheumatic diseases concurrent with or following COVID-19 infection. There was no language restriction. Studies describing manifestations that were less likely immune-mediated were excluded, such as manifestations with onset apparently before the COVID-19 symptoms or those very likely medication-related. Two authors (KT Tang and DY Chen) independently extracted data from these studies electronically. Our emphasis was on the temporal relationship between these manifestations and COVID-19 infection, other clinical evidence

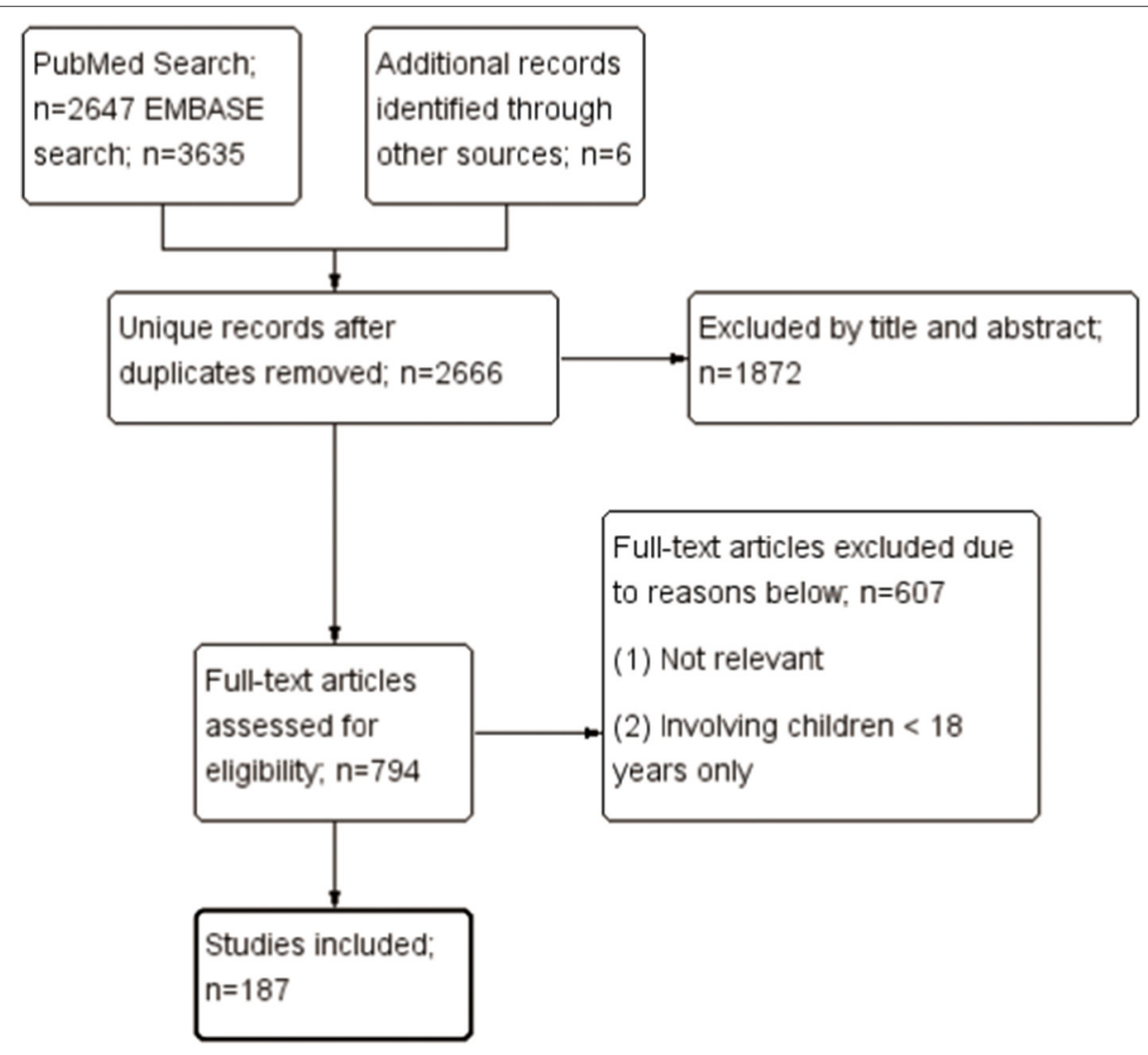

FIGURE 1 | Selection of studies to be included in the systematic review. 
supporting the immune-mediated mechanisms underlying these manifestations, the epidemiology of these manifestations, and therapeutic response to immunomodulating therapies.

\section{RESULTS \\ Overview}

Probably owning to the characteristics of SARS-CoV-2 and the elicited immune response, COVID-19 infection has been reported to be associated with a variety of autoimmune and rheumatic manifestations. Most of these manifestations have been associated with other microbial infections and their underlying immune-mediated mechanisms are evident. However, the existing data were mostly case reports or case series, and sometimes even conflicting; therefore a causal relationship could not be ascertained.

\section{Potential Molecular Mechanisms Contributing to Autoimmune and Rheumatic Manifestations} Severe Acute Respiratory Syndrome Coronavirus 2 (SARS-CoV-2)

Coronaviruses contain the largest single-stranded RNA in nature, and the SARS-CoV-2 genome is composed of around 30,000 nucleotides (4). The complex transcriptome, due to its discontinuous transcription and recombination activities, may further expand the ability to interact with the immune system (5). Additionally, the variability of protein sequences provides a rich source of epitopes to stimulate the immune system (6). These factors may contribute to the development of immune-mediated manifestations associated with COVID-19 infection.

\section{Molecular Mimicry}

It is well-known that microbial infection could lead to autoimmunity through three mechanisms: molecular mimicry, bystander activation, and epitope spreading (7). The possibility of molecular mimicry in COVID-19 disease has been proposed, and peptide sharing analysis revealed massive hexapeptide and heptapeptide sharing between SARS-CoV-2 spike glycoprotein and human proteins compared with other mammals and human coronaviruses (8). Another study also found hexapeptide sharing between viral epitopes and 460 human proteins (9). Interestingly, some of these proteins are associated with pulmonary, cardiac, vascular, coagulation, and immunological disorders. Other studies have demonstrated a similarity between SARS-CoV-2 and human proteins, including pulmonary surfactants (10), brainstem neuronal proteins (11), chaperons (12), heat shock proteins 60 and 90 (13), ankyrin 1 (an erythrocyte membrane protein) (14), odorant receptor 7D4, poly (ADP-ribose) polymerase family member 9 (PARP9), and solute carrier family 12 member 6 (SLC12A6) (15), which have been hypothesized to contribute to lung disease, respiratory failure, endothelitis, neuroimmune diseases, autoimmune hemolytic anemia (AIHA), leukopenia, and vascular damage. Also, three immunogenic epitopes with high sequence identity to viral proteins were found in patients with dermatomyositis (16). Of note, the monoclonal antibodies against SARS-CoV-2 spike protein and nucleoprotein could cross-react with various tissue proteins, such as nuclear antigens, extractable nuclear antigen, mitochondria, thyroglobulin, thyroid peroxidase, transglutaminases, myelin basic protein, actin, and $\alpha$-myosin (17). In summary, molecular similarities between viral and human proteins existed, but the clinical significance requires further verification.

\section{Autoantibodies}

As shown in Table 1, five studies reported the screening results of circulating autoantibodies in patients with COVID-19 (1721). Anti-nuclear antibodies (ANA) was found in $4-50 \%$ of COVID-19 patients, most of whom were older people. This was consistent with previous reports of an increased prevalence of autoantibodies in the elderly without autoimmune diseases (22). In accordance, Schiaffino et al. found an association between older age and the presence of autoantibodies in COVID-19 patients (17). Preliminary results of these studies indicated a higher incidence of neurologic and thrombotic events, and poor outcome in the autoantibody-positive subgroup compared with the autoantibody-negative subgroup $(17,18)$. However, the pathogenic potential of these autoantibodies, and whether these autoantibodies persist after resolution of COVID-19 infection, remains unclear. Interestingly, Bastard et al. demonstrated the presence of anti-type I interferon (IFN) antibodies in 10.2\% of 987 patients with life-threatening COVID-19 pneumonia, although they speculated that these antibodies might appear before COVID-19 infection (23). In summary, autoantibodies were prevalent in COVID-19 patients, albeit with unknown clinical significance.

\section{Cytokine Storm}

COVID-19 triggers an exaggerated immune response in infected patients, and a variety of inflammatory cytokines, such as interleukin (IL)-1 $\beta$, IL-6, IL-8, interferon (IFN)$\gamma$, and chemokines, such as granulocyte colony stimulating factor (G-CSF), interferon gamma-induced protein 10 (IP-10), monocyte chemoattractant protein-1 (MCP-1), and macrophage inflammatory protein $1 \alpha$ (MIP- $1 \alpha)$, were elevated in severe COVID-19 patients $(24,25)$. In particular, a meta-analysis has demonstrated a nearly 3-fold higher serum levels of IL-6 in patients with complicated COVID-19 when compared with those patients with non-complicated disease (26). Regulatory T cells were also below normal levels in COVID-19 patients, which further aggravate the inflammatory response (27). Ultimately, the resultant cytokine storm leads to tissue damage and multiple organ failure. Clinically, inflammatory markers, such as Creactive protein, procalcitonin, D-dimer, and ferritin, were increased in COVID-19 patients and associated with a poor prognosis (28). Taken together, the uncontrolled inflammatory milieu triggered by COVID-19 infection may lead to organ damage and the generation of autoimmunity, too.

\section{Systemic Autoimmune and Rheumatic Manifestations \\ Arthritis}

Articular symptoms are often observed in virus infection, with the severity ranging from arthralgia, acute arthritis, to 
TABLE 1 | Prevalence of circulating autoantibodies in patients with COVID-19 disease.

\begin{tabular}{|c|c|c|c|c|c|c|}
\hline Study & $\begin{array}{c}\text { Reference } \\
\text { number }\end{array}$ & Country & Patients & $\begin{array}{l}\text { Mean/median } \\
\text { age (years) }\end{array}$ & $\begin{array}{l}\text { Proportion } \\
\text { of males }\end{array}$ & Autoantibodies \\
\hline Pascolini et al. & 18 & Italy & $\begin{array}{l}33 \text { referred } \\
\text { patients }\end{array}$ & 70 (range 22-90) & $52 \%$ & $\begin{array}{l}\text { ANA detected by IFA on HEp-2 cells ( } 33 \%) \text {, } \\
\text { anti-histone antibody detected by immunoblot ( } 3 \% \text { ), } \\
\text { but negative for autoantibodies against Sm and } \\
\text { RNP/Sm, RNP70, A, and C, SSA-Ro52, SSA-Ro60, } \\
\text { SSB, Scl-70, PM-Scl, Jo-1, CENP-B, PCNA, } \\
\text { dsDNA, nucleosomes, ribosomal P protein, and M2 } \\
\text { detected by immunoblot, ANCA detected by IFA, } \\
\text { and anti-PR3 and anti-MPO antibodies detected by } \\
\text { FEIA }\end{array}$ \\
\hline Schiaffino et al. & 19 & Spain & $\begin{array}{l}53 \text { hospitalized } \\
\text { patients }\end{array}$ & 64 (IQR 24-91) & $58 \%$ & $\begin{array}{l}\text { ANA detected by unknown method (3.8\%), IgG/M } \\
\text { autoantibodies against hepatocytes and gastric } \\
\text { glandular cells detected by IFA on rat } \\
\text { kidney/stomach/liver ( } 23 \%)\end{array}$ \\
\hline $\begin{array}{l}\text { Vlachoyiannopoulos } \\
\text { et al. }\end{array}$ & 20 & Greece & 29 ICU patients & 64 (range 43-85) & $72 \%$ & $\begin{array}{l}\text { ANA detected by unknown method (34.5\%), } \\
\text { anti-CCP detected by ELISA ( } 3.5 \%), \text { c-ANCA } \\
\text { detected by immunofluorescence (6.9\%), and } \\
\text { p-ANCA detected by immunofluorescence ( } 6.9 \%) \text {, } \\
\text { but negative for anti-ENA detected by immunoblot, } \\
\text { and anti-dsDNA, anti-PR3 and anti-MPO antibodies } \\
\text { detected by ELISA }\end{array}$ \\
\hline Vojdani et al. & 17 & USA & 5 patients & N.A. & N.A. & $\begin{array}{l}\text { ANA, anti-ENA, anti-actin and anti-mitochondrial } \\
\text { antibodies detected by unknown methods ( } 60 \%) \text {, } \\
\text { but negative for anti-dsDNA antibody and RF } \\
\text { detected by unknown methods }\end{array}$ \\
\hline Zhou et al. & 21 & China & 21 ICU patients & 66 (SD 13) & $62 \%$ & $\begin{array}{l}\text { ANA (50\%), anti-Ro52 (20\%), anti-Ro60 ( } 25 \%) \text {, } \\
\text { anti-Scl-70 (5\%), and anti-U1-RNP antibodies (5\%), } \\
\text { but negative for autoantibodies against Jo-1, } \\
\text { centromere B, SmD1, SSB and dsDNA (all detected } \\
\text { by chemiluminescence immunoassay) }\end{array}$ \\
\hline
\end{tabular}

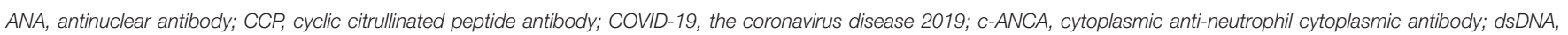

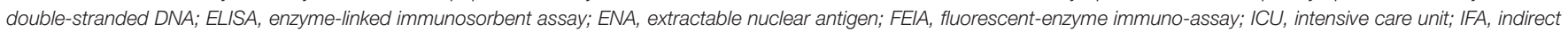

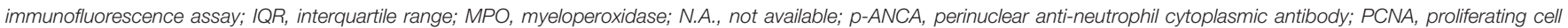
nuclear antigen; PR3, proteinase 3; RF, rheumatoid factor; RNP, ribonucleoprotein; SD, standard deviation.

chronic arthritis (29). Only two studies reported the prevalence of arthralgia alone, instead of myalgia/arthralgia, in COVID19 patients, which were $31 \%$ of 417 patients with COVID19 from 12 European hospitals and $2.5 \%$ of 40 patients in Thailand, respectively $(30,31)$. Five cases of acute mono-, oligo, or polyarthritis as an initial presentation (32) or a delayed phenomenon 3-29 days after COVID-19 symptoms onset (3336) have been reported. Two cases had accompanying features of reactive arthritis, such as enthesitis and urethritis $(35,36)$. Using RT-PCR, negative SARS-CoV-2 RNA in joint fluid was demonstrated in two cases $(33,36)$, implying that the arthritis was mediated by immune mechanisms rather than direct viral invasion. Acute arthritis either resolved spontaneously (33) or responded to treatment with non-steroidal anti-inflammatory drugs (NSAIDs), corticosteroids, and even baricitinib (32, 3436). Nevertheless, two acute arthritis patients did not enter remission at follow-up despite treatment $(32,35)$. Furthermore, insufficient follow-up time in these reports might miss out on the opportunity to observe arthritis recurrences after arthritis remission and being drug-free, since infection-related reactive arthritis may persist for years (37). Development of chronic arthritis concurrent with SARS-CoV-2 infection was found in a 45-year-old male, which responded to corticosteroids (38).
Another 50-year-old female also demonstrated worsening of pre-existing rheumatoid arthritis (RA), which improved after sarilumab treatment (32). In summary, SARS-CoV-2 infection was associated with the development of arthralgia, acute arthritis, and possibly, chronic arthritis.

\section{Antiphospholipid Antibody Syndrome (APS)}

As demonstrated in Table 2, the presence of antiphospholipid antibodies (aPL) has been observed in COVID-19 patients around the world (18-20,39-55). The association between aPL and disease severity was shown in three studies $(39,54,56)$, but not in another study (46). Lupus anticoagulant and non-criteria IgA anti- $\beta 2$ glycoprotein-I/anticardiolipin antibodies (57) were the most prevalent aPL, with the prevalence of 3-92, 0-37, and $0-32 \%$ in patients with moderate to severe disease (Figure 2). However, the lupus anticoagulant testing might be interfered by heparin use or elevated C-reactive protein in COVID-19 patients. IgG anticardiolipin and anti- $\beta 2$ glycoprotein-I antibodies were also prevalent, but often in low titers. Notably, one study revealed $3(5 \%)$ of 58 COVID-19 patients had a highly thrombogenic anti- $\beta 2$ glycoprotein-I domain I IgG antibody, although not correlated with thrombosis (41). The strong association of aPL with thrombotic events was not observed in most studies, even 
TABLE 2 | Prevalence of antiphospholipid autoantibodies in COVID-19 disease.

\begin{tabular}{|c|c|c|c|c|c|c|c|}
\hline Study & $\begin{array}{l}\text { Reference } \\
\text { number }\end{array}$ & Country & Patients & $\begin{array}{l}\text { Mean/median age } \\
\text { (years) }\end{array}$ & $\begin{array}{l}\text { Proportion of } \\
\text { males }\end{array}$ & Prevalence of aPL & Findings \\
\hline $\begin{array}{l}\text { Amezcua-Guerra } \\
\text { et al. }\end{array}$ & 39 & Mexico & 21 ICU patients & 62 (IQR 54-67) & $43 \%$ & $\begin{array}{l}\text { Anti-annexin V IgG (5\%), anti-annexin V IgM (19\%), ACA IgG } \\
(10 \%) \text {, ACA IgM (14\%), AB2GPI IgG (5\%), AB2GPI IgM (0\%), aPT } \\
\text { IgG (0\%), aPT IgM (5\%), aPS IgG (10\%), aPS IgM (14\%), aPI IgG } \\
(0 \%) \text {, and aPI IgM (0\%)* }\end{array}$ & $\begin{array}{l}\text { Elevated levels of interleukin-6/ferritin/C-reactive } \\
\text { protein only in patients with aPL; pulmonary embolism } \\
\text { in two aPL+ patients but in no aPL- patients }\end{array}$ \\
\hline Bertin et al. & 40 & France & $\begin{array}{l}56 \text { patients with } \\
\text { moderate and severe } \\
\text { disease }\end{array}$ & 67 & $59 \%$ & $\begin{array}{l}\text { ACA IgG (29\%), ACA IgM (5\%), AB2GPI IgG (2\%), and AB2GPI } \\
\operatorname{lgM}(7 \%)^{*}\end{array}$ & ACA IgG was associated with severe disease \\
\hline Borghi et al. & 41 & Italy & $\begin{array}{l}122 \text { patients with } \\
\text { severe disease }\end{array}$ & 69 (SD 16) & $63 \%$ & $\begin{array}{l}\text { ACA IgG (6\%), ACA IgM (7\%), AB2GPI IgG (16\%), AB2GPI IgG } \\
\text { domain I (5\%), AB2GPI IgM (9\%), AB2GPI IgA (7\%), aPS/PT IgG } \\
(3 \%) \text {, and aPS/PT IgM (10\%)* }\end{array}$ & $\begin{array}{l}\text { No association between aPL and thrombotic events, } \\
\text { even for AB2GPI domain I IgG }\end{array}$ \\
\hline Bowles et al. & 42 & UK & $\begin{array}{l}35 \text { patients with a } \\
\text { prolonged aPTT }\end{array}$ & 57 (95\%Cl 19-83) & $69 \%$ & LA $(53 \%)^{* \star}$ & \\
\hline Cuenca Saez et al. & 43 & Spain & $\begin{array}{l}11 \text { patients with } \\
\text { perniosis }\end{array}$ & (range 2-40) & N.A. & $\begin{array}{l}\text { LA (0\%), ACA IgG (0\%), ACA IgM (0\%), and low titer ACA IgA } \\
(100 \%)\end{array}$ & \\
\hline Devreese et al. & 44 & Belgium & 31 ICU patients & 63 (range 38-82) & $90 \%$ & $\begin{array}{l}\text { LA (68\%), ACA IgG (0\%), ACA IgM (3\%), ACA IgA (10\%), AB2GPI } \\
\text { IgG (3\%), AB2GPI IgM (3\%), AB2GPI IgA (10\%), aPS/PT IgG } \\
(10 \%) \text {, and aPS/PT IgM (13\%) }\end{array}$ & No association between aPL and thrombotic events \\
\hline Galeano-Valle et al. & 45 & Spain & $\begin{array}{l}24 \text { patients with } \\
\text { venous } \\
\text { thromboembolism }\end{array}$ & 64 (SD 14) & $58 \%$ & $\begin{array}{l}\text { ACA IgG (0\%), low titer ACA IgM (8.3\%), AB2GPI IgG (0\%), and } \\
\text { low titer AB2GPI IgM (8.3\%) }\end{array}$ & \\
\hline Gatto et al. & 46 & Italy & $\begin{array}{l}122 \text { patients with mild } \\
\text { to severe disease }\end{array}$ & 54 (SD 19) & $49 \%$ & $\begin{array}{l}\text { LA (22\%)**, ACA IgG (13\%), ACA IgM (3\%), ACA IgA (2\%), } \\
\text { AB2GPI IgG (6\%), AB2GPI IgM (7\%), and AB2GPI IgA (3\%) }\end{array}$ & $\begin{array}{l}\text { A trend toward an association between } \mathrm{aPL} \text { and } \\
\text { thrombotic events }\end{array}$ \\
\hline $\begin{array}{l}\text { Gutierrez López de } \\
\text { Ocáriz et al. }\end{array}$ & 47 & Spain & $\begin{array}{l}27 \text { hospitalized } \\
\text { patients }\end{array}$ & 58 (range 20-90) & $44 \%$ & $\begin{array}{l}\text { LA (22\%)**, ACA IgG (0\%), ACA IgM (0\%), AB2GPI IgG (0\%), } \\
\text { AB2GPI IgM (0\%) and AB2GPI IgA (4\%)* }\end{array}$ & No association between aPL and thrombotic events \\
\hline Harzallah et al. & 48 & France & 56 patients & N.A. & N.A. & LA $(45 \%)^{\star \star}$ and ACA IgG/M/AB2GPI lgG/M (10\%) & \\
\hline Pascolini et al. & 18 & Italy & $\begin{array}{l}33 \text { hospitalized } \\
\text { patients }\end{array}$ & 70 (range 22-90) & $52 \%$ & $\begin{array}{l}\text { ACA IgG (9\%), ACA IgM (15\%), AB2GPI IgG (6\%), and AB2GPI } \\
\operatorname{lgM}(6 \%)^{*}\end{array}$ & None of the patients had thrombotic events \\
\hline $\begin{array}{l}\text { Pineton de Chambrun } \\
\text { et al. }\end{array}$ & 49 & France & 25 ICU patients & 48 (range 35-64), & $68 \%$ & $\begin{array}{l}\text { LA (92\%), ACA IgG (12\%), ACA IgM (0\%), ACA IgA (8\%), AB2GPI } \\
\text { IgG (0\%), AB2GPI IgM (0\%), and AB2GPI IgA (8\%) }\end{array}$ & Massive pulmonary embolism in 6 patients, all aPL+ \\
\hline Previtali et al. & 50 & Italy & 35 deceased patients & 73 (range 52-82) & $74 \%$ & $\begin{array}{l}\text { Low titer ACA IgG (3\%), low titer ACA IgM (6\%), ACA IgA }(0 \%) \text {, } \\
\text { AB2GPI IgG (0\%), AB2GPI IgM (0\%), low titer aPS/PT IgG (3\%), } \\
\text { and low titer aPS/PT IgM }(6 \%)\end{array}$ & $\begin{array}{l}\text { Catastrophic APS was less likely despite multiple } \\
\text { thrombosis at autopsies }\end{array}$ \\
\hline Reyes Gil et al. & 51 & USA & 68 patients & 57 & $50 \%$ & $\begin{array}{l}\text { LA (60\%)**, ACA IgG (0\%), ACA IgM (1\%), AB2GPI IgG (0\%), and } \\
\text { AB2GPI lgM (1\%)* }\end{array}$ & LA associated with thrombotic events \\
\hline Schiaffino et al. & 19 & Spain & $\begin{array}{l}53 \text { hospitalized } \\
\text { patients }\end{array}$ & 64 (range 24-91) & $58 \%$ & $\begin{array}{l}\text { ACA IgG (2\%), ACA IgM (9\%), AB2GPI IgG (2\%), and AB2GPI IgM } \\
(6 \%)^{*}\end{array}$ & No association between aPL and thrombotic events \\
\hline Siguret et al. & 52 & France & $\begin{array}{l}74 \text { mechanically } \\
\text { ventilated patients }\end{array}$ & 64 & N.A. & LA (85\%) and ACA IgG/lgM/AB2GPI IgG (12\%)* & No association between aPL and thrombotic events \\
\hline Tvito et al. & 53 & Israel & $\begin{array}{l}43 \text { patients with mild } \\
\text { to severe disease }\end{array}$ & N.A. & $63 \%$ & $\begin{array}{l}\text { LA (37\%)**, ACA IgG (0\%), ACA IgM (0\%), AB2GPI IgG (0\%), and } \\
\text { AB2GPI IgM (0\%) }\end{array}$ & No association between aPL and thrombotic events \\
\hline $\begin{array}{l}\text { Vlachoyiannopoulos } \\
\text { et al. }\end{array}$ & 20 & Greece & 29 ICU patients & 64 (range 43-85) & $72 \%$ & $\begin{array}{l}\text { ACA IgG (24\%), ACA IgM (10\%), ABGPI IgG (17\%), and ABGPI } \\
\operatorname{lgM}(28 \%)^{*}\end{array}$ & \\
\hline Xiao et al. & 54 & China & 66 ICU patients & 65 & $59 \%$ & $\begin{array}{l}\text { LA (3\%), ACA IgG (6\%), ACA IgM (3\%), ACA IgA (26\%), AB2GPI } \\
\text { IgG (18\%), AB2GPI IgM (2\%), AB2GPI IgA (29\%), aPS/PT IgG } \\
(0 \%) \text {, and APS/PT IgM (11\%)* }\end{array}$ & $\begin{array}{l}\text { Patients with multiple aPLs had a significantly higher } \\
\text { incidence of cerebral infarction }\end{array}$ \\
\hline Zhang et al. & 55 & China & 19 ICU patients & 65 (IQR 60-70) & $53 \%$ & $\begin{array}{l}\text { LA (5\%), ACA IgG (11\%), ACA IgM (5\%), ACA IgA }(32 \%) \text {, AB2GPI } \\
\text { IgG (32\%), AB2GPI IgM (0\%), and AB2GPI IgA }(37 \%)^{*}\end{array}$ & $\begin{array}{l}\text { All } 4 \text { patients with cerebral infarction had aPL with } \\
\text { multiple isotypes whereas no thrombotic events } \\
\text { developed in aPL-patients. }\end{array}$ \\
\hline
\end{tabular}

*Probably including low titer aPL as positive.

AB2GPI, anti- $\beta 2$ 2glycoprotein I; ACA, anticardiolipin antibody; aPI, antiphosphatidylinositol antibody; aPL, antiphospholipid antibodies; aPS, anti-phosphotidylserine antibody; aPT, antiprothrombin antibody; aPTT, activated partial-thromboplastin time; Cl, confidence interval; COVID-19, the coronavirus disease 2019; ICU, intensive care unit; IQR, interquartile range; LA, lupus anticoagulant; N.A., not available; SD, standard deviation. 
A

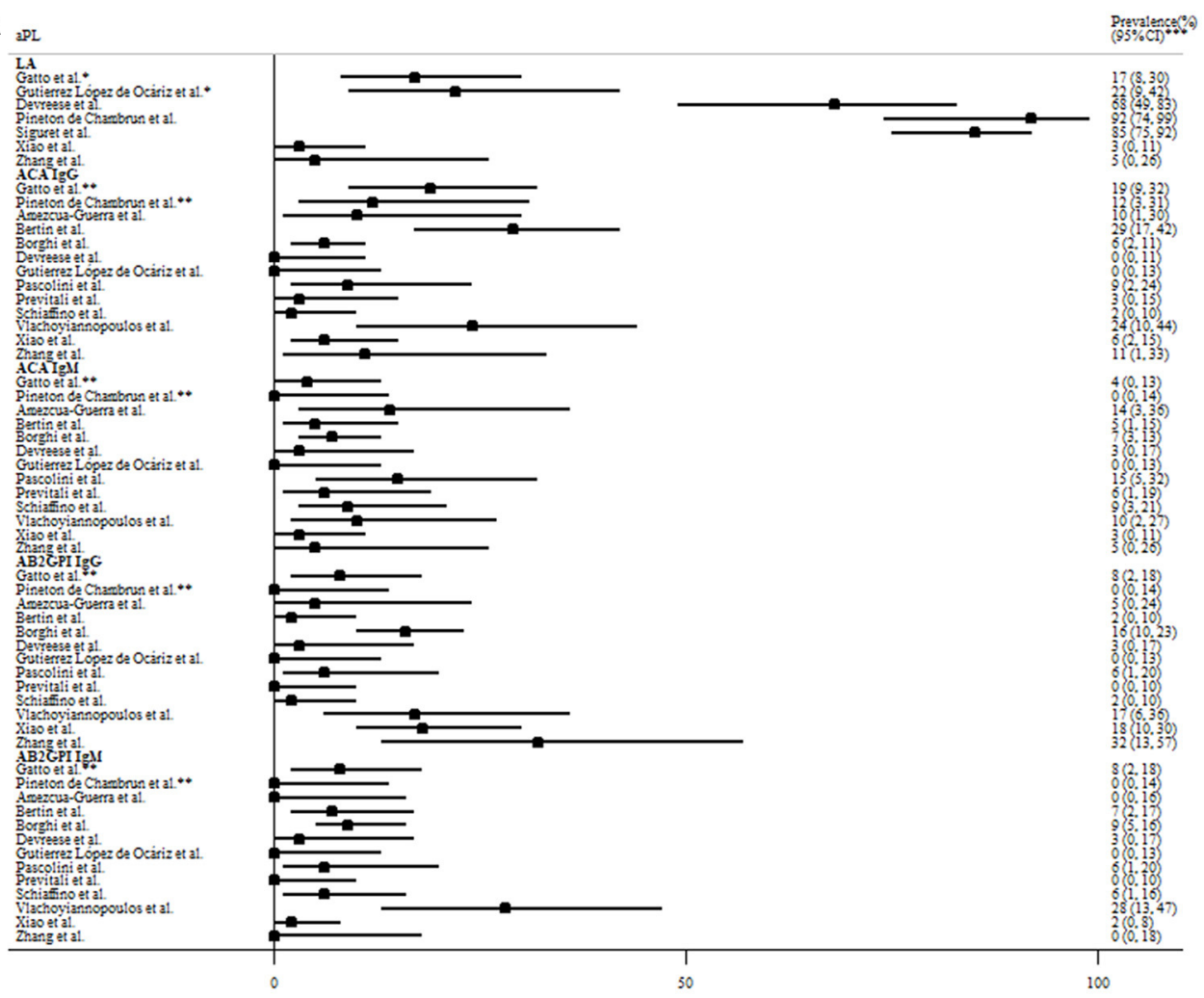

B apL

Prevalences:\%)

ACAIgA

Geweese th at.

Previtali et al.

Xiaoet al.

Thang et al.

AB2GPI IgA

Gitto et at "*

Borghi et al.

Devreese et at.

Gutierez López de Ocáriz et al.

Previtali et at.

Xiao et al.

Zhang et at.

aPT IgG
Arescua-Guerra at

Aroezcua-G
aPT IgMI

Amezcua-Guera et al

aPS IgG

Asescua-Guera et al.

aPS IgM

Amescus-Guerra et a1

aPS/PT IgG

Borghi et a1.

Daveese et al.

Previtali et

Xiao et al.
aPS PT IgM

Borghi et a1.

Downesse at at.

previtali et at.

Xiao et a1.

APII IgG

Amezcua-G
aPI IgM

API IgM

Acozcua-Gverra et al.

Anti-anderin IgG

Awezcus-Gverra et al

Anszcua-Guerra et a1.

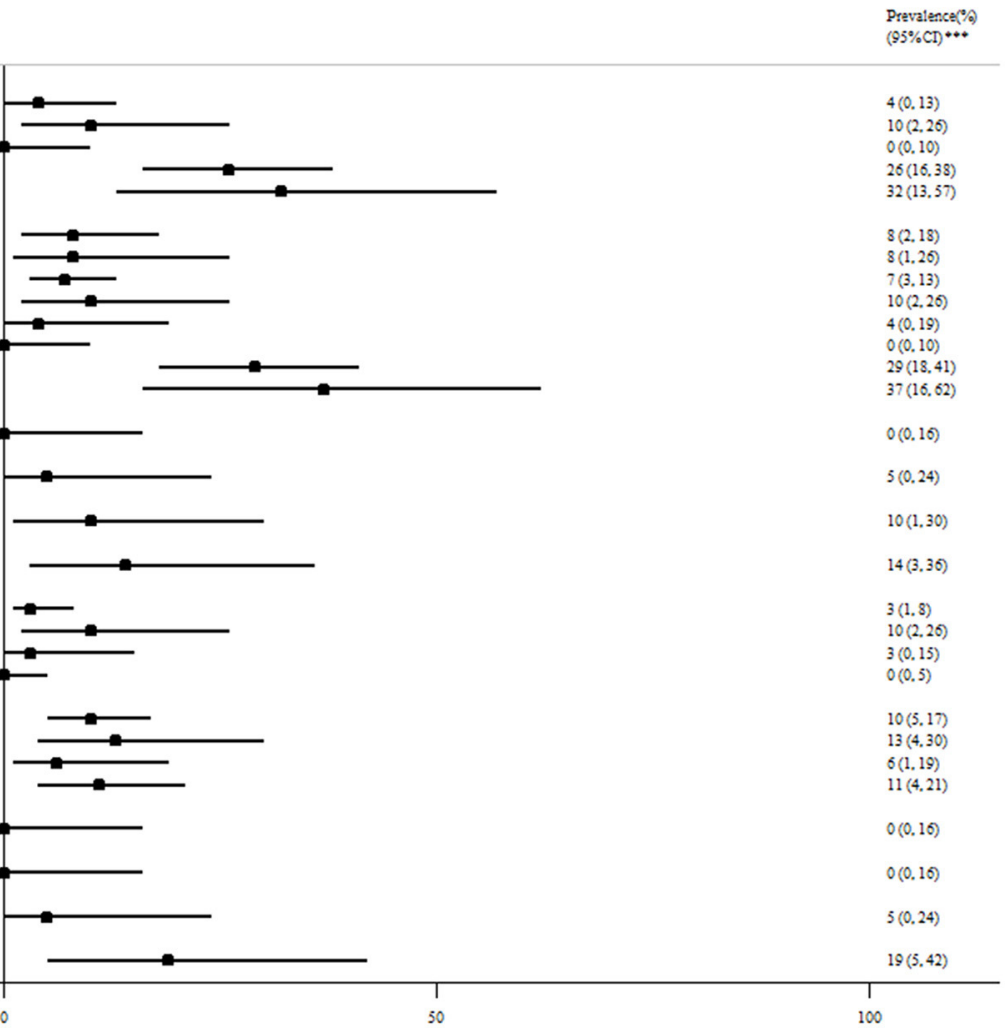

FIGURE 2 | The prevalence of (A) criteria and (B) non-criteria antiphospholipid antibodies (aPL) based on the revised Sapporo criteria for antiphospholipid antibody syndrome in COVID-19 patients with moderate to severe disease. *Determined by two tests based on different principles per the International Society of Thrombosis and Haemostasis criteria. ${ }^{\star \star}$ Moderate-to-high titer aPL. ${ }^{\star \star \star} 95 \%$ exact confidence intervals. AB2GPI, anti- $\beta 2$ glycoprotein I antibody; ACA, anticardiolipin antibody; aPI, antiphosphatidylinositol antibody; aPL, antiphospholipid antibodies; aPS, antiphosphotidylserine antibody; aPT, antiprothrombin antibody; COVID-19, the coronavirus disease 2019; LA, lupus anticoagulant. 
for patients with double/triple positivity. Besides, repeated testing showed that the titer of aPL fluctuated during the disease course $(52,54)$, and the aPL turned to be negative 1 month later in most of the aPL-positive patients (44).

COVID-19 was associated with the flares of pre-existing APS. The complications include bilateral adrenal glands hemorrhage in a 66-year-old female and limb ischemia in another 48-yearold male, both of which were controlled by anticoagulants $(58,59)$. Interestingly, one study revealed $5(63 \%)$ of eight pregnant women with COVID-19 infection fulfilled diagnostic criteria for pre-eclampsia/HELLP syndrome (hemolysis; elevated liver enzymes; low platelet count), perhaps due to overlapping features. Only one of them was more likely to have pre-eclampsia, an obstetric complication of APS (60). However, aPL were not examined in these pregnant women. In summary, low titer and transient aPL were prevalent in COVID-19 patients, but like aPL generated in other infections, most of them were not pathogenic.

\section{Multisystem Inflammatory Syndrome in Adults (MIS-A)}

Pediatric cases of Kawasaki-like multisystem inflammatory syndrome (MIS-C) are accumulating mainly in Western countries. With a favorable prognosis, the disease was characterized by hyper-inflammation, gastrointestinal symptoms, and cardiac dysfunction, such as myocarditis, and shock, which were somewhat different from classical Kawasaki disease. Multisystem inflammatory syndrome associated with COVID-19 infection has also been found in adults (MIS-A) aged 35-54 years (61-64). Like children, these adult patients were reported in Western countries and recovered after treatment with corticosteroids, intravenous immunoglobulin (IVIG), and tocilizumab, an IL-6 receptor inhibitor. An IL-1 receptor antagonist, anakinra, may also be a therapeutic option based on the experiences in children (65). Although some did not undergo complete coronary evaluation, none of these adult patients had dilatation or aneurysm. Interestingly, isolated myocarditis has also been reported in two adult COVID-19 patients: one 28-year-old woman presented with myocarditis shortly after COVID-19 infection, which improved after methylprednisolone pulse therapy (66); the other 53-year-old woman developed myocarditis a week after COVID-19 symptoms onset, which was stabilized by corticosteroids (67).

\section{Systemic Vasculitis}

An autopsy study in Italy revealed vasculitis in the lung, brain, and other organs in individuals who succumbed to COVID-19 (68). Clinical evidence for systemic vasculitis was limited to case reports. A 69-year-old woman and a 71year-old man presented with asymptomatic aortitis and had concurrent SARS-CoV-2 infection (69, 70). A 73-year-man presented with arterial vasculitis at splenic hilum resulting in splenic infarction concomitantly with COVID-19 infection. The condition improved after splenectomy (71). Another 71year-old man developed abdominal and bilateral common iliac arteritis concurrent with COVID-19 infection, with subsequent spontaneous remission (70). Concurrent ileocecal vasculitic ulcers was found in a 40-year-old female COVID-19 patient, who then only received supportive treatment (72). Notably, virus particles have been found in the cytoplasm of vascular endothelial cells in the biopsy specimen of one patient (72), whereas SARS-CoV-2 RT-PCR was negative in another patient's biopsy (71). A 37-year-old woman suffered from anti-proteinase 3 (PR3)-positive diffuse alveolar hemorrhage concurrent with SARS-CoV-2 infection and later received treatments of intravenous methylprednisolone pulse therapy, plasmapheresis, and IVIG. Her hemoptysis improved after IVIG, but finally she expired while on ventilator (73). Two cases were reported on anti-neutrophilic cytoplasmic antibodies (ANCA)associated vasculitis with necrotizing nephritis concomitant with COVID-19 infection. They responded to methylprednisolone pulse therapy plus rituximab (74). Henoch-Schönlein purpura with nephritis was found in a 78-year-old man 3 weeks after COVID-19 infection. His condition improved after methylprednisolone pulse therapy and rituximab (75). HenochSchönlein purpura with suspected gastrointestinal involvement occurred in another 24-year-old man, and improved after corticosteroids treatment (76). In summary, case reports of large, medium, and small vessel vasculitis involving multiple organs have been reported in COVID-19 patients. However, we could not ascertain whether these vasculitis resulted from direct virusinduced endothelitis or immune-mediated mechanisms.

\section{Other Systemic Autoimmune Rheumatic Diseases (SARDs)}

Three cases of new onset SLE concurrent with COVID-19 infection have been published, and two of them eventually deceased (77-79). In other studies, myositis of proximal limbs and paraspinal myositis have been demonstrated on magnetic resonance imaging (MRI) along with elevated creatine kinase in one and seven COVID-19 patients, respectively $(80,81)$. However, a complete workup, such as electromyography and muscle biopsy, was lacking in these cases. None of them received treatment due to being either in critical conditions or asymptomatic. In a Chinese cohort of 21 COVID-19 patients with pre-existing SARDs, a disease flare was demonstrated in one SLE patient (skin rashes and hemolytic anemia), one ankylosing spondylitis patient (back and ankle pain), and one patient with polymyalgia rheumatica (muscle pain), whose symptoms were attenuated after treatment with hydroxychloroquine, NSAID, corticosteroids, or mycophenolate mofetil (82). Another Italian multicenter cohort reported 40 (17\%) of 232 SARD patients with moderate to severe disease activity upon COVID-19 infection but provided no further details (83). The Asia Pacific Lupus Collaboration (APLC) cohort reported three cases of SARS-CoV2 -infected SLE patients, two of whom developed a concurrent lupus flare (thrombocytopenia and nephritis) and improved after corticosteroids and IVIG treatment (84). Another two SARSCoV-2-infected SLE patients presented with an exacerbation of thrombocytopenia, which were successfully treated with corticosteroids and IVIG $(85,86)$. In summary, SARDs, especially SLE, might flare upon COVID-19 infection. Nevertheless, the overlapping features between the wide spectrum of COVID19 manifestations and SARDs made the distinction ambiguous. Furthermore, medication adherence in these patients was 
questionable during the pandemic, which might also contribute to a flare of SARDs.

\section{Hemophagocytic Lymphohistiocytosis (HLH)}

Infection is a well-known trigger factor of HLH. In fact, severe COVID-19 patients presented with hyperferritinemia and cytokine storm, reminiscent of HLH. Autopsy studies demonstrated a high percentage of hemophagocytosis in COVID-19 patients' bone marrow, pulmonary lymph nodes, or spleen, ranging from 75 to $94 \%(87,88)$. Using a validated hemophagocytic syndrome diagnostic score (HScore) cut-off point of 168 (89), we identified a total of 15 cases of COVID19-associated HLH (Table 3) (88, 90-94). However, the reported prevalence of HLH in severe COVID-19 patients was as low as 7\% $(93,94)$. Notably, routine examinations for serum triglycerides and fibrinogen, hepatosplenomegaly, or tissue hemophagocytosis were not always performed in these studies. In summary, COVID-19 infection was associated with HLH in a few cases as defined by the HScore.

\section{Organ-Specific Immune-Related Manifestations \\ Hematological Manifestations}

Thrombocytopenia is common but usually mild in COVID19 infection. Chen et al. reviewed 271 hospitalized COVID-19 patients and found the prevalence of delayed thrombocytopenia 14 days after COVID symptoms to be $12 \%$. The authors speculated that it was partly immune-mediated (95). Table 4 demonstrated 38 cases of immune thrombocytopenic purpura (ITP) associated with COVID-19 infection, and some of them only had mild or asymptomatic COVID-19 (90, 96-113). Most of these patients with thrombocytopenia were diagnosed by exclusion and had a favorable response to corticosteroids, IVIG, and even thrombopoietin receptor agonists. Positive direct Coomb's test was shown in 13\% of 267 anemic COVID-19 patients and $46 \%$ of the other 113 COVID-19 patients $(114,115)$. Furthermore, both warm and cold AIHA have been reported in COVID-19 patients and most of them recovered spontaneously (116-122). In line with these findings, a 39-year-old man was found to have concomitant Evans syndrome and COVID19 infection (123). Autoimmune thrombotic thrombocytopenic purpura has been demonstrated in two COVID-19 patients and improved after plasmapheresis $(124,125)$. Another 66year-old man whose acquired hemophilia flared concomitantly with COVID-19 infection, responded to corticosteroids and cyclophosphamide (126). In summary, many cases of ITP or AIHA associated with COVID-19 have been reported, implying a possible link between them.

\section{Skin Manifestations}

Case series had been reported in Western countries on Raynaud's phenomenon and chilblains-like lesions in patients with recent COVID-19 infection (positive anti-SARS-CoV-2 IgG) or in close contact with confirmed COVID-19 cases (127-130). Some biopsies revealed positive findings for vasculitis or vascular microthrombi, but negative findings for SARS-CoV-2 based on RT-PCR. Biopsy-proven cases had been reported on cutaneous vasculitis, manifesting as purpuric papules (131) and plaques (132, 133), hemorrhagic bullae (134), and urticarial (135, 136), and targetoid lesions (137). Most of these conditions occurred 5-35 days after onset of COVID-19 symptoms and they responded well to topical or oral corticosteroids. Besides, livedo reticularis developed without aPL in a 57-year-old man concomitant with COVID-19 infection (138). Flares of psoriasis or newly-developed psoriatic arthritis concurrent with or following COVID-19 infection had been reported. These conditions had resolved either spontaneously or after NSAID and topical corticosteroids treatment (139-141). In summary, cutaneous vasculitis were potentially associated with COVID-19 infection, mainly in the Western population.

\section{Neurological Manifestations}

A spectrum of neurological manifestations, including neuroimmune manifestations were presented in COVID-19 patients. The frequencies of these manifestations in hospitalized patients are as follows: encephalitis $0.1-0.2 \%$, GBS $0.1-1 \%$, myelitis $0.1 \%$, and optic neuritis $0.1 \%$ in Western countries (142-144). In Singapore, two cases of acute disseminated

TABLE 3 | Hemophagocytic lymphohistiocytosis (HLH) in COVID-19 disease.

\begin{tabular}{|c|c|c|c|c|c|c|c|}
\hline Study & $\begin{array}{l}\text { Reference } \\
\text { number }\end{array}$ & Country & $\begin{array}{l}\text { Patient } \\
\text { number }\end{array}$ & $\begin{array}{l}\text { Age (years), } \\
\text { median (range) }\end{array}$ & Sex & $\begin{array}{c}\text { HSscore, } \\
\text { median (range) }\end{array}$ & Treatment response \\
\hline Debliquis et al. & 90 & France & 1 & 63 & $1 \mathrm{M}$ & 207 & Deceased without specific treatment \\
\hline Dimopoulos et al. & 91 & $\begin{array}{l}\text { Greece and the } \\
\text { Netherlands }\end{array}$ & 8 & $68(51,84)$ & $7 \mathrm{M} 1 \mathrm{~F}$ & $175(171,188)$ & $\begin{array}{l}\text { Decreased HScore after anakinra but } \\
3(38 \%) \text { of them eventually deceased }\end{array}$ \\
\hline Faguer et al. & 92 & France & 1 & 51 & $1 \mathrm{M}$ & 253 & Decreased HScore after tocilizumab \\
\hline Hakim et al. & 93 & USA & 1 & 37 & $1 \mathrm{M}$ & 204 & $\begin{array}{l}\text { Decreased HScore after tocilizumab } \\
\text { but eventually deceased on ventilator }\end{array}$ \\
\hline Prilutskiy et al. & 88 & USA & 1 & 72 & $1 \mathrm{M}$ & 217 & $\begin{array}{l}\text { Hemophagocytosis found } \\
\text { post-mortem despite anakinra }\end{array}$ \\
\hline Wood et al. & 94 & UK & 3 & N.A. & N.A. & N.A. & $\begin{array}{l}\text { Decreased HScore after tocilizumab } \\
\text { but then contracting a bacterial } \\
\text { pneumonia }\end{array}$ \\
\hline
\end{tabular}

COVID-19, the coronavirus disease 2019; N.A., not available. 
TABLE 4 | Cases of immune thrombocytopenic purpura (ITP) in COVID-19 disease.

\begin{tabular}{|c|c|c|c|c|c|}
\hline Study & $\begin{array}{l}\text { Reference } \\
\text { number }\end{array}$ & Age (years) & $\begin{array}{l}\text { Patient number } \\
\text { and sex }\end{array}$ & Findings & Treatment response \\
\hline Artru et al. & 96 & 38 & $1 \mathrm{M}$ & & Responsive to corticosteroids and IVIG \\
\hline Bomhof et al. & 98 & $59,66,67$ & $2 \mathrm{M} 1 \mathrm{~F}$ & & $\begin{array}{l}\text { Two responsive to corticosteroids and IVIG, } \\
\text { and one died of intracerebral bleeding despite } \\
\text { platelet transfusion }\end{array}$ \\
\hline Deruelle et al. & 99 & 41 & $1 \mathrm{M}$ & $\begin{array}{l}\text { Increased megakaryocytes at bone } \\
\text { marrow biopsy }\end{array}$ & Responsive to IVIG \\
\hline Hindilerden et al. & 100 & 86 & $1 \mathrm{M}$ & $\begin{array}{l}\text { Increased megakaryocytes at bone } \\
\text { marrow biopsy }\end{array}$ & Responsive to corticosteroids \\
\hline Mahevas et al. & 104 & $\begin{array}{l}\text { Median } 64 \text { (range } \\
53-79 \text { ) }\end{array}$ & $7 \mathrm{M} 7 \mathrm{~F}$ & & All responsive to corticosteroids and IVIG \\
\hline Malik et al. & 105 & 29 & $1 \mathrm{~F}$ & $\begin{array}{l}\text { Increased megakaryocytes at bone } \\
\text { marrow biopsy }\end{array}$ & Responsive to corticosteroids \\
\hline Martincic et al. & 106 & 48 & $1 \mathrm{M}$ & & Responsive to corticosteroids and IVIG \\
\hline Murt et al. & 107 & 41 & $1 \mathrm{M}$ & & Responsive to IVIG \\
\hline Nesr et al. & 108 & 34 & $1 \mathrm{~F}$ & History of ITP, pregnant & Responsive to corticosteroids and IVIG \\
\hline Pascolini et al. & 109 & 31,69 , and 88 & $2 \mathrm{M} 1 \mathrm{~F}$ & Positive IgM antiplatelet antibodies & Recovery after resolution of COVID-19 infection \\
\hline Patel et al. & 110 & 67 & $1 \mathrm{M}$ & & Responsive to romiplostim \\
\hline Revuz et al. & 111 & 39,57 , and 76 & $2 \mathrm{M} 1 \mathrm{~F}$ & & All responsive to IVIG \\
\hline
\end{tabular}

COVID-19, the coronavirus disease 2019; IVIG, intravenous immunoglobulin.

encephalomyelitis (ADEM), two encephalitis, and one GBS were reported among 47,572 COVID-19 cases (145). The development of encephalitis and GBS were generally delayed after COVID-19 symptoms onset. MRI-proven central nervous system vasculitis occurred in two patients 11-29 days after COVID-19 symptoms onset and responded to either corticosteroids or tocilizumab (146, 147). Using RT-PCR or antibody testing, if available, cerebrospinal fluid SARS-CoV-2 were positive in only some of these cases (144). Most neuroimmune diseases patients responded to standard immunomodulating therapies.

A 29-year-old woman developed multiple sclerosis with right optic neuritis 2-3 weeks after COVID-19 infection (148). Another 26-year-old man had myelin oligodendrocyte glycoprotein antibody-positive neuromyelitis optica, presenting as bilateral optic neuritis and longitudinal extensive transverse myelitis a few days after COVID-19 symptoms onset and responsive to methylprednisolone pulse therapy (149). Also, a study of 76 patients with multiple sclerosis demonstrated disease recrudescence preceding or concurrent with COVID19 in $16(21 \%)$ (150). There were reports of newly-onset acetylcholine receptor antibody-positive myasthenia gravis (MG)
5-7 days after COVID-19 symptoms onset, which responded to pyridostigmine, corticosteroids, IVIG and plasmapheresis (151). In a cohort of $15 \mathrm{MG}$ patients with concomitant SARS-CoV-2 infection, a high percentage of them experienced MG worsening (87\%) and even mechanical ventilation $(73 \%)$, although it was difficult to ascertain exacerbated respiratory muscle weakness in patients with concomitant pneumonia and respiratory failure (152). However, 8 (62\%) of them recovered after treated with corticosteroids, IVIG or plasmapheresis. In another cohort, one (20\%) of 5 SARS-CoV-2-infected MG patients experienced MG worsening (ptosis and dysphagia) but responded to corticosteroids plus IVIG (153). In summary, a myriad of neuroimmune manifestations might develop concurrently with or following SARS-CoV-2 infection. However, it was difficult to differentiate between direct neuronal infection and immunemediated mechanisms underlying these manifestations.

\section{Interstitial Lung Disease (ILD)}

Lung involvement is critical in COVID-19 infection. Chest computed tomography (CT) demonstrated interlobular septal and interstitial thickening in $0.88 \%$ of 130 infected inpatients at 
Wuhan (154). In accordance, autopsy of COVID-19 patients with critical illness showed interstitial mononuclear inflammatory infiltrates, organizing pneumonia, or fibrosis in the lung (155, 156). Long-term follow-ups of SARS survivors had residual fibrosis on chest radiographs and accompanying respiratory dysfunction 6 months later (157). Similarly, a subset of COVID19 patients displayed interstitial change 2 weeks after disease onset (158) or upon discharge (159), as well as decreased diffusing capacity for carbon monoxide (DLCO) (160). However, a longer follow-up is required to monitor the progression of pulmonary interstitial change after COVID-19 infection to determine if these changes are merely post-ARDS change or progressive ILD.

\section{Ocular Manifestations}

Retinal vein vasculitic occlusion was found in a 52-year-old man 10 days after COVID-19 symptoms appeared, but his visual acuity improved after treatment with corticosteroids and intravitreal anti-vascular endothelial growth factor (anti-VEGF) injection (161). Another 54-year-old woman developed bilateral anterior uveitis 14 days after COVID-19-associated MIS-A but responded to topical corticosteroids (61).

\section{Other Organ-Specific Immune-Related Manifestations}

Crescentic glomerulonephritis had been found in two COVID19 patients, which stabilized after methylprednisolone pulse therapy, plasmapheresis, IVIG and cyclophophomide (162). Collapsing glomerulopathy concomitant with COVID-19 infection was reported in two cases, with virus-like particles found in their renal biopsies $(163,164)$. In the North West London, eight unexpected new cases of Goodpasture syndrome were diagnosed, representing a 5 -fold increase of the background rate, and four of them were positive for IgM and/or IgG antibodies to SARS-CoV-2 (165). However, the clinical significance required further research. A 19-year-old woman developed ulcerative colitis 9 days after the resolution of COVID-19 infection (166). A cross-sectional study of 82 patients with inflammatory bowel disease (IBD) revealed an IBD flare in one (1\%) patient during SARS-CoV-2 infection (167). In another study of 79 IBD patients infected with SARS-CoV-2 revealed 4 (5\%) patients had severe concomitant IBD flare (168). Finally, subacute thyroiditis has been reported in an 18-year-old woman 15 days after diagnosis of COVID-19, which improved after corticosteroids therapy (169).

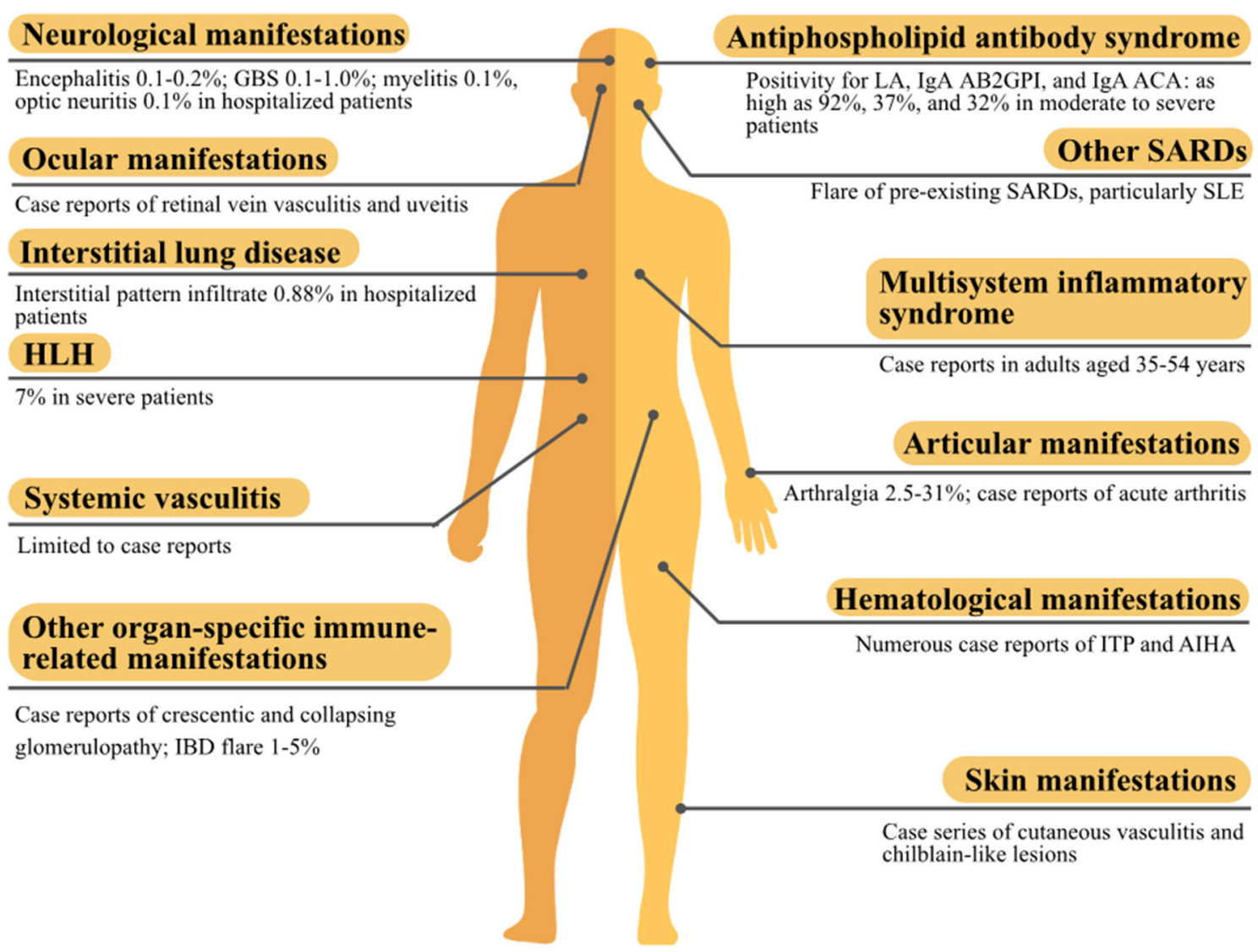

FIGURE 3 | The summary of autoimmune and rheumatic manifestations associated with the coronavirus disease 2019 (COVID-19). AB2GPI, anti- $\beta 2$ glycoprotein I antibody; ACA, anticardiolipin antibody; AlHA, autoimmune hemolytic anemia; GBS, Guillain-Barré syndrome; HLH, hemophagocytic lymphohistiocytosis; IBD, inflammatory bowel disease; ITP, immune thrombocytopenic purpura; LA, lupus anticoagulant; SARD, systemic autoimmune rheumatic disease; SLE, systemic lupus erythematosus. 


\section{DISCUSSION}

\section{Limitations}

Some limitations should be addressed. First, most of the clinical evidence was not systematic and based on case reports or case series without a long-term follow-up. Second, the sensitivity and specificity of different testing kits for SARSCoV-2 infection were not well-validated, and the false positive or negative results could undermine our appraisal of the literature. Third, most of the reports were from patients with moderate to severe COVID-19 disease. It was impossible to determine the epidemiology of these manifestations in asymptomatic and mild COVID-19 cases. Fourth, overlapping COVID-19 features and concomitant medications could make it difficult to determine if these manifestations were immunemediated. Fifth, it was difficult to assure whether direct cytopathic effect consequent to viral invasion or immunemediated mechanisms were responsible for these manifestations. Lastly, the immunomodulators often used to treat these manifestations are also potential therapies for COVID-19. It was hard to know whether the immunomodulators exert their beneficial effect directly upon the immune mechanisms underlying these manifestations or indirectly through the alleviation of COVID-19 infection. However, there are no immunomodulating therapies that have consistently shown therapeutic efficacy toward SARS-CoV-2.

\section{Conclusions}

SARS-CoV-2 has a complex transcriptome and shares molecular similarities with human proteins, and its infection could generate various autoantibodies and cytokine storm, which form the basis for developing autoimmune and rheumatic manifestations. Accordingly, a variety of systemic or organspecific manifestations have been reported to be associated with COVID-19 (summarized in Figure 3). Most of these manifestations have been reported in other microbial infections except for MIS-A. MIS-A shared some similarities with Kawasaki disease, but the distinct differences between the two entities made MIS-A more likely to be specific to

\section{REFERENCES}

1. Johns Hopkins University. Coronavirus Resource Center. Available online at: https://coronavirus.jhu.edu/map.html (accessed December 25, 2020).

2. Rodriguez Y, Novelli L, Rojas M, De Santis M, Acosta-Ampudia Y, Monsalve DM, et al. Autoinflammatory and autoimmune conditions at the crossroad of COVID-19. J Autoimmun. (2020) 114:102506. doi: 10.1016/j.jaut.2020.102506

3. Ehrenfeld M, Tincani A, Andreoli L, Cattalini M, Greenbaum A, Kanduc D, et al. Covid-19 and autoimmunity. Autoimmun Rev. (2020) 19:102597. doi: 10.1016/j.autrev.2020.102597

4. Naqvi AaT, Fatima K, Mohammad T, Fatima U, Singh IK, Singh A, et al. Insights into SARS-CoV-2 genome, structure, evolution, pathogenesis and therapies: Structural genomics approach. Biochim Biophys Acta. (2020) 1866:165878. doi: 10.1016/j.bbadis.2020.165878

5. Kim D, Lee JY, Yang JS, Kim JW, Kim VN, Chang H. The architecture of SARS-CoV-2 transcriptome. Cell. (2020) 181:914-21 e910. doi: 10.1016/j.cell.2020.04.011
SARS-CoV-2. In general, these manifestations were effectively treated in a strategy similarly used for patients without concomitant infection. Spontaneous recovery could happen but was uncommon, although expectant management was rarely undertaken in these patients. Based on the temporal relationship (sometimes delayed after COVID19 infection resolves), well-known immune-mediated mechanisms, and treatment response to immunomodulators, these manifestations were probably consequences of the immune dysregulation caused by COVID-19 infection, particularly autoimmune cytopenia, cutaneous vasculitis, encephalitis, and GBS. But the evidence was still conflicting as regards to manifestations, such as APS, HLH, and MG. Herein, we provided a comprehensive overview of the evidence and literature concerning these rare but clinically significant manifestations; vaccine developers should take these findings into account in their vaccine design and post-marketing surveillance.

\section{DATA AVAILABILITY STATEMENT}

The raw data supporting the conclusions of this article will be made available by the authors, without undue reservation, upon request to the corresponding author.

\section{AUTHOR CONTRIBUTIONS}

$\mathrm{K}-\mathrm{TT}, \mathrm{B}-\mathrm{CH}$, and D-YC performed the literature search and retrieved relevant articles. K-TT and D-YC appraised the selected articles and drafted the manuscript. All authors made substantive intellectual contributions to the present study and approved the final manuscript.

\section{SUPPLEMENTARY MATERIAL}

The Supplementary Material for this article can be found online at: https://www.frontiersin.org/articles/10.3389/fimmu. 2021.645013/full\#supplementary-material
6. V'kovski P, Kratzel A, Steiner S, Stalder H, Thiel V. Coronavirus biology and replication: implications for SARS-CoV-2. Nat Rev Microbiol. (2021) 19:155-70. doi: 10.1038/s41579-020-00468-6

7. Fujinami RS, Von Herrath MG, Christen U, Whitton JL. Molecular mimicry, bystander activation, or viral persistence: infections and autoimmune disease. Clin Microbiol Rev. (2006) 19:80-94. doi: 10.1128/CMR.19.1.80-94.2006

8. Kanduc D, Shoenfeld Y. Molecular mimicry between SARS-CoV-2 spike glycoprotein and mammalian proteomes: implications for the vaccine. Immunol Res. (2020) 68:310-3. doi: 10.1007/s12026-020-09152-6

9. Kanduc D. From anti-SARS-CoV-2 immune responses to COVID-19 via molecular mimicry. Antibodies (Basel). (2020) 9:33. doi: 10.3390/antib9030033

10. Kanduc D, Shoenfeld Y. On the molecular determinants of the SARS-CoV-2 attack. Clin Immunol. (2020) 215:108426. doi: 10.1016/j.clim.2020.108426

11. Lucchese G, Floel A. Molecular mimicry between SARS-CoV2 and respiratory pacemaker neurons. Autoimmun Rev. (2020) 19:102556. doi: 10.1016/j.autrev.2020.102556 
12. Marino Gammazza A, Legare S, Lo Bosco G, Fucarino A, Angileri F, Conway De Macario E, et al. Human molecular chaperones share with SARSCoV-2 antigenic epitopes potentially capable of eliciting autoimmunity against endothelial cells: possible role of molecular mimicry in COVID19. Cell Stress Chaperones. (2020) 25:737-41. doi: 10.1007/s12192-020-0 1148-3

13. Lucchese G, Floel A. SARS-CoV-2 and Guillain-Barre syndrome: molecular mimicry with human heat shock proteins as potential pathogenic mechanism. Cell Stress Chaperones. (2020) 25:7315. doi: 10.1007/s12192-020-01145-6

14. Angileri F, Legare S, Marino Gammazza A, Conway De Macario E, Macario AJL, Cappello F. Is molecular mimicry the culprit in the autoimmune haemolytic anaemia affecting patients with COVID-19? $\mathrm{Br}$ J Haematol. (2020) 190:e92-3. doi: 10.1111/bjh.16883

15. Angileri F, Legare S, Marino Gammazza A, Conway De Macario E, Jl Macario A, Cappello F. Molecular mimicry may explain multi-organ damage in COVID-19. Autoimmun Rev. (2020) 19:102591. doi: 10.1016/j.autrev.2020.102591

16. Megremis S, Walker TDJ, He X, Ollier WER, Chinoy H, Hampson L, et al. Antibodies against immunogenic epitopes with high sequence identity to SARS-CoV-2 in patients with autoimmune dermatomyositis. Ann Rheum Dis. (2020) 79:1383-6. doi: 10.1136/annrheumdis-2020-217522

17. Vojdani A, Kharrazian D. Potential antigenic cross-reactivity between SARSCoV-2 and human tissue with a possible link to an increase in autoimmune diseases. Clin Immunol. (2020) 217:108480. doi: 10.1016/j.clim.2020.108480

18. Pascolini S, Vannini A, Deleonardi G, Ciordinik M, Sensoli A, Carletti I, et al. COVID-19 and immunological dysregulation: can autoantibodies be useful? Clin Transl Sci. (2020). doi: 10.1111/cts.12908. [Epub ahead of print].

19. Schiaffino MT, Di Natale M, Garcia-Martinez E, Navarro J, Munoz-Blanco JL, Demelo-Rodriguez P, et al. Immunoserologic detection and diagnostic relevance of cross-reactive autoantibodies in coronavirus disease 2019 patients. J Infect Dis. (2020) 222:1439-43. doi: 10.1093/infdis/jiaa485

20. Vlachoyiannopoulos PG, Magira E, Alexopoulos H, Jahaj E, Theophilopoulou K, Kotanidou A, et al. Autoantibodies related to systemic autoimmune rheumatic diseases in severely ill patients with COVID-19. Ann Rheum Dis. (2020) 79:1661-3. doi: 10.1136/annrheumdis-2020-218009

21. Zhou Y, Han T, Chen J, Hou C, Hua L, He S, et al. Clinical and autoimmune characteristics of severe and critical cases of COVID-19. Clin Transl Sci. (2020) 13:1077-86. doi: 10.1111/cts.12805

22. Vadasz Z, Haj T, Kessel A, Toubi E. Age-related autoimmunity. BMC Med. (2013) 11:94. doi: 10.1186/1741-7015-11-94

23. Bastard P, Rosen LB, Zhang Q, Michailidis E, Hoffmann HH, Zhang Y, et al. Autoantibodies against type I IFNs in patients with life-threatening COVID-19. Science. (2020) 370:eabd4585. doi: 10.1126/science.abd4585

24. Tang Y, Liu J, Zhang D, Xu Z, Ji J, Wen C. Cytokine storm in COVID19: the current evidence and treatment strategies. Front Immunol. (2020) 11:1708. doi: 10.3389/fimmu.2020.01708

25. Huang C, Wang Y, Li X, Ren L, Zhao J, Hu Y, et al. Clinical features of patients infected with 2019 novel coronavirus in Wuhan, China. Lancet. (2020) 395:497-506. doi: 10.1016/s0140-6736(20)30183-5

26. Coomes EA, Haghbayan H. Interleukin-6 in Covid-19: a systematic review and meta-analysis. Rev Med Virol. (2020) 30:1-9. doi: 10.1002/rmv.2141

27. Qin C, Zhou L, Hu Z, Zhang S, Yang S, Tao Y, et al. Dysregulation of immune response in patients with coronavirus 2019 (COVID-19) in Wuhan, China. Clin Infect Dis. (2020) 71:762-8. doi: 10.1093/cid/ciaa248

28. Zeng F, Huang Y, Guo Y, Yin M, Chen X, Xiao L, et al. Association of inflammatory markers with the severity of COVID-19: a meta-analysis. Int J Infect Dis. (2020) 96:467-74. doi: 10.1016/j.ijid.2020.05.055

29. Marks M, Marks JL. Viral arthritis. Clin Med (Lond). (2016) 16:12934. doi: 10.7861/clinmedicine.16-2-129

30. Lechien JR, Chiesa-Estomba CM, De Siati DR, Horoi M, Le Bon SD, Rodriguez A, et al. Olfactory and gustatory dysfunctions as a clinical presentation of mild-to-moderate forms of the coronavirus disease (COVID19): a multicenter European study. Eur Arch Otorhinolaryngol. (2020) 277:2251-61. doi: 10.1007/s00405-020-05965-1

31. Joob B, Wiwanitkit V. Arthralgia as an initial presentation of COVID-19: observation. Rheumatol Int. (2020) 40:823. doi: 10.1007/s00296-020-04561-0
32. Alivernini S, Cingolani A, Gessi M, Paglionico A, Pasciuto G, Tolusso B, et al. Comparative analysis of synovial inflammation after SARS-CoV-2 infection. Ann Rheum Dis. (2020). doi: 10.1136/annrheumdis-2020-218315. [Epub ahead of print].

33. Yokogawa N, Minematsu N, Katano H, Suzuki T. Case of acute arthritis following SARS-CoV-2 infection. Ann Rheum Dis. (2020). doi: 10.1136/annrheumdis-2020-218281. [Epub ahead of print].

34. Saricaoglu EM, Hasanoglu I, Guner R. The first reactive arthritis case associated with COVID-19. J Med Virol. (2021) 93:192-3. doi: 10.1002/jmv.26296

35. Ono K, Kishimoto M, Shimasaki T, Uchida H, Kurai D, Deshpande GA, et al. Reactive arthritis after COVID-19 infection. RMD Open. (2020) 6:e001350. doi: 10.1136/rmdopen-2020-001350

36. Liew IY, Mak TM, Cui L, Vasoo S, Lim XR. A case of reactive arthritis secondary to coronavirus disease 2019 infection. J Clin Rheumatol. (2020) 26:233. doi: 10.1097/RHU.0000000000001560

37. Garcia Ferrer HR, Azan A, Iraheta I, Von Feldt J, Espinoza LR, Manasson J, et al. Potential risk factors for reactive arthritis and persistence of symptoms at 2 years: a case-control study with longitudinal follow-up. Clin Rheumatol. (2018) 37:415-22. doi: 10.1007/s10067-017-3911-3

38. Talarico R, Stagnaro C, Ferro F, Carli L, Mosca M. Symmetric peripheral polyarthritis developed during SARS-CoV-2 infection. The Lancet Rheumatology. (2020) 2:e518-9. doi: 10.1016/s2665-9913(20)30216-2

39. Amezcua-Guerra LM, Rojas-Velasco G, Brianza-Padilla M, VazquezRangel A, Marquez-Velasco R, Baranda-Tovar F, et al. Presence of antiphospholipid antibodies in COVID-19: case series study. Ann Rheum Dis. (2020). doi: 10.1136/annrheumdis-2020-218100. [Epub ahead of print].

40. Bertin D, Brodovitch A, Beziane A, Hug S, Bouamri A, Mege JL, et al. Anticardiolipin IgG autoantibody level is an independent risk factor for COVID-19 severity. Arthritis Rheumatol. (2020) 72:195355. doi: 10.1002/art.41409

41. Borghi MO, Beltagy A, Garrafa E, Curreli D, Cecchini G, Bodio C, et al. Anti-phospholipid antibodies in COVID-19 are different from those detectable in the anti-phospholipid syndrome. Front Immunol. (2020) 11:584241. doi: 10.3389/fimmu.2020.584241

42. Bowles L, Platton S, Yartey N, Dave M, Lee K, Hart DP, et al. Lupus anticoagulant and abnormal coagulation tests in patients with Covid-19. N Engl J Med. (2020) 383:288-90. doi: 10.1056/NEJMc2013656

43. Cuenca Saez MA, Gomez-Biezna SL. Immunoglobulin A antiphospholipid antibodies in patients with chilblain-like lesions during the COVID-19 pandemic. Actas Dermosifiliogr. (2020). doi: 10.1016/j.ad.2020.08.006. [Epub ahead of print].

44. Devreese KMJ, Linskens EA, Benoit D, Peperstraete H. Antiphospholipid antibodies in patients with COVID-19: a relevant observation? J Thromb Haemost. (2020) 18:2191-201. doi: 10.1111/jth.14994

45. Galeano-Valle F, Oblitas CM, Ferreiro-Mazon MM, Alonso-Munoz J, Del Toro-Cervera J, Di Natale $M$, et al. Antiphospholipid antibodies are not elevated in patients with severe COVID-19 pneumonia and venous thromboembolism. Thromb Res. (2020) 192:113-5. doi: 10.1016/j.thromres.2020.05.017

46. Gatto M, Perricone C, Tonello M, Bistoni O, Cattelan AM, Bursi R, et al. Frequency and clinical correlates of antiphospholipid antibodies arising in patients with SARS-CoV-2 infection: findings from a multicentre study on 122 cases. Clin Exp Rheumatol. (2020) 38:754-9.

47. Gutierrez Lopez De Ocariz X, Castro Quismondo N, Vera Guerrero E, Rodriguez Rodriguez M, Ayala Diaz R, Martinez Lopez J. Thrombosis and antiphospholipid antibodies in patients with SARS-COV-2 infection (COVID-19). Int J Lab Hematol. (2020) 42:e280-2. doi: 10.1111/ijlh.13320

48. Harzallah I, Debliquis A, Drenou B. Lupus anticoagulant is frequent in patients with Covid-19. J Thromb Haemost. (2020) 18:2064-5. doi: 10.1111/jth.14867

49. Pineton De Chambrun M, Frere C, Miyara M, Amoura Z, Martin-Toutain I, Mathian A, et al. High frequency of antiphospholipid antibodies in critically ill COVID-19 patients: a link with hypercoagulability? J Intern Med. (2020). doi: 10.1111/joim.13126. [Epub ahead of print].

50. Previtali G, Seghezzi M, Moioli V, Sonzogni A, Cerutti L, Marozzi R, et al. The pathogenesis of thromboembolic disease in covid-19 patients: could be 
a catastrophic antiphospholipid syndrome? Thromb Res. (2020) 194:1924. doi: 10.1016/j.thromres.2020.06.042

51. Reyes Gil M, Barouqa M, Szymanski J, Gonzalez-Lugo JD, Rahman $\mathrm{S}$, Billett HH. Assessment of lupus anticoagulant positivity in patients with coronavirus disease 2019 (COVID-19). JAMA Netw Open. (2020) 3:e2017539. doi: 10.1001/jamanetworkopen.2020.17539

52. Siguret V, Voicu S, Neuwirth M, Delrue M, Gayat E, Stepanian A, et al. Are antiphospholipid antibodies associated with thrombotic complications in critically ill COVID-19 patients? Thromb Res. (2020) 195:74-6. doi: 10.1016/j.thromres.2020.07.016

53. Tvito A, Ben-Chetrit E, Zimmerman FS, Asher E, Helviz Y. Lupus anticoagulant in patients with COVID-19. Int J Lab Hematol. (2021) 43:e178. doi: $10.1111 /$ ijlh.13334

54. Xiao M, Zhang Y, Zhang S, Qin X, Xia P, Cao W, et al. Antiphospholipid antibodies in critically ill patients with COVID-19. Arthritis Rheumatol. (2020) 72:1998-2004. doi: 10.1002/art.41425

55. Zhang Y, Cao W, Jiang W, Xiao M, Li Y, Tang N, et al. Profile of natural anticoagulant, coagulant factor and anti-phospholipid antibody in critically ill COVID-19 patients. J Thromb Thrombolysis. (2020) 50:5806. doi: 10.1007/s11239-020-02182-9

56. Hasan Ali O, Bomze D, Risch L, Brugger SD, Paprotny M, Weber M, et al. Severe COVID-19 is associated with elevated serum IgA and antiphospholipid IgA-antibodies. Clin Infect Dis. (2020). doi: 10.1093/cid/ciaa1496. [Epub ahead of print].

57. Liu T, Gu J, Wan L, Hu Q, Teng J, Liu H, et al. "Non-criteria" antiphospholipid antibodies add value to antiphospholipid syndrome diagnoses in a large Chinese cohort. Arthritis Res Ther. (2020) 22:33. doi: 10.1186/s13075-020-2131-4

58. Frankel M, Feldman I, Levine M, Frank Y, Bogot NR, Benjaminov $\mathrm{O}$, et al. Bilateral adrenal hemorrhage in coronavirus disease 2019 patient: a case report. J Clin Endocrinol Metab. (2020) 105:37459. doi: 10.1210/clinem/dgaa487

59. Maria ATJ, Diaz-Cau I, Benejean JM, Nutz A, Schiffmann A, Biron-Andreani C, et al. Flare of antiphospholipid syndrome in the course of COVID-19. TH Open. (2020) 4:e207-10. doi: 10.1055/s-0040-1716735

60. Mendoza M, Garcia-Ruiz I, Maiz N, Rodo C, Garcia-Manau P, Serrano B, et al. Pre-eclampsia-like syndrome induced by severe COVID-19: a prospective observational study. BJOG. (2020) 127:1374-80. doi: 10.1111/1471-0528.16339

61. Bettach E, Zadok D, Weill Y, Brosh K, Hanhart J. Bilateral anterior uveitis as a part of a multisystem inflammatory syndrome secondary to COVID-19 infection. J Med Virol. (2021) 93:139-40. doi: 10.1002/jmv.26229

62. Shaigany $S$, Gnirke $M$, Guttmann A, Chong $H$, Meehan $S$, Raabe V, et al. An adult with Kawasaki-like multisystem inflammatory syndrome associated with COVID-19. Lancet. (2020) 396:e8-10. doi: 10.1016/s0140-6736(20)31526-9

63. Sokolovsky S, Soni P, Hoffman T, Kahn P, Scheers-Masters J. COVID-19 associated Kawasaki-like multisystem inflammatory disease in an adult. Am J Emerg Med. (2020) 39:253.e1-2. doi: 10.1016/j.ajem.2020.06.053

64. Lidder AK, Pandit SA, Lazzaro DR. An adult with COVID-19 Kawasakilike syndrome and ocular manifestations. Am J Ophthalmol Case Rep. (2020) 20:100875. doi: 10.1016/j.ajoc.2020.100875

65. Feldstein LR, Rose EB, Horwitz SM, Collins JP, Newhams MM, Son MBF, et al. Multisystem inflammatory syndrome in U.S. children and adolescents. N Engl J Med. (2020) 383:334-46. doi: 10.1056/NEJMoa2021680

66. Richard I, Robinson B, Dawson A, Aya A, Ali R. An atypical presentation of fulminant myocarditis secondary to COVID-19 infection. Cureus. (2020) 12:e9179. doi: 10.7759/cureus.9179

67. Inciardi RM, Lupi L, Zaccone G, Italia L, Raffo M, Tomasoni D, et al. Cardiac involvement in a patient with coronavirus disease 2019 (COVID-19). JAMA Cardiol. (2020) 5:819-24. doi: 10.1001/jamacardio.202 0.1096

68. Boraschi P. COVID-19 pulmonary involvement: is really an interstitial pneumonia? Acad Radiol. (2020) 27:900. doi: 10.1016/j.acra.2020.04.010

69. Salvat Davila C, Suarez Fernandez JP, Dominguez Grande ML, Vigil Diaz C, Fernandez Llana B, Martin Fernandez N, et al. SARSCoV-2 (COVID-19) pneumonia: incidental finding on (18)F-FDG
PET/CT study for vasculitis diagnosis. Rev Esp Med Nucl Imagen Mol. (2020). doi: 10.1016/j.remn.2020.06.013. [Epub ahead of print].

70. Oda R, Inagaki T, Ishikane M, Hotta M, Shimomura A, Sato M, et al. Case of adult large vessel vasculitis after SARS-CoV-2 infection. Ann Rheum Dis. (2020). doi: 10.1136/annrheumdis-2020-218440. [Epub ahead of print].

71. Vacchi C, Meschiari M, Milic J, Marietta M, Tonelli R, Alfano G, et al. COVID-19-associated vasculitis and thrombotic complications: from pathological findings to multidisciplinary discussion. Rheumatology (Oxford). (2020) 59:e147-50. doi: 10.1093/rheumatology/keaa581

72. Carnevale S, Beretta P, Morbini P. Direct endothelial damage and vasculitis due to SARS-CoV-2 in small bowel submucosa of COVID-19 patient with diarrhea. J Med Virol. (2021) 93:61-3. doi: 10.1002/jmv.26119

73. Hussein A, Al Khalil K, Bawazir YM. Anti-neutrophilic cytoplasmic antibody (ANCA) vasculitis presented as pulmonary hemorrhage in a positive COVID-19 patient: a case report. Cureus. (2020) 12:e9643. doi: 10.7759/cureus. 9643

74. Uppal NN, Kello N, Shah HH, Khanin Y, De Oleo IR, Epstein E, et al. De novo ANCA-associated vasculitis with glomerulonephritis in COVID-19. Kidney Int Rep. (2020) 5:2079-83. doi: 10.1016/j.ekir.2020.08.012

75. Suso AS, Mon C, Onate Alonso I, Galindo Romo K, Juarez RC, Ramirez CL, et al. IgA vasculitis with nephritis (henoch-schonlein purpura) in a COVID19 patient. Kidney Int Rep. (2020) 5:2074-8. doi: 10.1016/j.ekir.2020.08.016

76. Allez M, Denis B, Bouaziz JD, Battistella M, Zagdanski AM, Bayart J, et al. COVID-19-related IgA vasculitis. Arthritis Rheumatol. (2020) 72:19523. doi: $10.1002 /$ art. 41428

77. Bonometti R, Sacchi MC, Stobbione P, Lauritano EC, Tamiazzo S, Marchegiani A, et al. The first case of systemic lupus erythematosus (SLE) triggered by COVID-19 infection. Eur Rev Med Pharmacol Sci. (2020) 24:9695-7. doi: 10.26355/eurrev_202009_23060

78. Slimani Y, Abbassi R, El Fatoiki FZ, Barrou L, Chiheb S. Systemic lupus erythematosus and varicella-like rash following COVID-19 in a previously healthy patient. J Med Virol. (2021) 93:1184-7. doi: 10.1002/jmv.26513

79. Mantovani Cardoso E, Hundal J, Feterman D, Magaldi J. Concomitant new diagnosis of systemic lupus erythematosus and COVID-19 with possible antiphospholipid syndrome. Just a coincidence? A case report and review of intertwining pathophysiology. Clin Rheumatol. (2020) 39:28115. doi: 10.1007/s10067-020-05310-1

80. Beydon M, Chevalier K, Al Tabaa O, Hamroun S, Delettre AS, Thomas M, et al. Myositis as a manifestation of SARS-CoV-2. Ann Rheum Dis. (2021) 80:e42. doi: 10.1136/annrheumdis-2020-217573

81. Mehan WA, Yoon BC, Lang M, Li MD, Rincon S, Buch K. Paraspinal myositis in patients with COVID-19 infection. Am J Neuroradiol. (2020) 41:1949-52. doi: 10.3174/ajnr.A6711

82. Ye C, Cai S, Shen G, Guan H, Zhou L, Hu Y, et al. Clinical features of rheumatic patients infected with COVID-19 in Wuhan, China. Ann Rheum Dis. (2020) 79:1007-13. doi: 10.1136/annrheumdis-2020-217627

83. Scire CA, Carrara G, Zanetti A, Landolfi G, Chighizola C, Alunno A, et al. COVID-19 in rheumatic diseases in Italy: first results from the Italian registry of the Italian Society for Rheumatology (CONTROL-19). Clin Exp Rheumatol. (2020) 38:748-53.

84. Cho J, Kandane-Rathnayake R, Louthrenoo W, Hoi A, Golder V, Chen YH, et al. COVID-19 infection in patients with systemic lupus erythematosus: data from the Asia Pacific Lupus Collaboration. Int J Rheum Dis. (2020) 23:1255-7. doi: 10.1111/1756-185X.13937

85. Kondo Y, Kaneko Y, Oshige T, Fukui H, Saito S, Okayama M, et al. Exacerbation of immune thrombocytopaenia triggered by COVID19 in patients with systemic lupus erythematosus. Ann Rheum Dis. (2020). doi: 10.1136/annrheumdis-2020-218157. [Epub ahead of print].

86. Merli M, Ageno W, Sessa F, Salvini M, Caramazza D, Mora B, et al. Recurrence of immune thrombocytopenia at the time of SARS-CoV-2 infection. Ann Hematol. (2020) 99:1951-2. doi: 10.1007/s00277-020-04130-2

87. Prieto-Perez L, Fortes J, Soto C, Vidal-Gonzalez A, Alonso-Riano M, Lafarga M, et al. Histiocytic hyperplasia with hemophagocytosis and acute alveolar damage in COVID-19 infection. Mod Pathol. (2020) 33:213946. doi: 10.1038/s41379-020-0613-1

88. Prilutskiy A, Kritselis M, Shevtsov A, Yambayev I, Vadlamudi C, Zhao Q, et al. SARS-CoV-2 infection-associated hemophagocytic 
lymphohistiocytosis. Am J Clin Pathol. (2020) 154:46674. doi: 10.1093/ajcp/aqaa124

89. Knaak C, Nyvlt P, Schuster FS, Spies C, Heeren P, Schenk T, et al. Hemophagocytic lymphohistiocytosis in critically ill patients: diagnostic reliability of HLH-2004 criteria and HScore. Crit Care. (2020) 24:244. doi: 10.1186/s13054-020-02941-3

90. Debliquis A, Harzallah I, Mootien JY, Poidevin A, Labro G, Mejri A, et al. Haemophagocytosis in bone marrow aspirates in patients with COVID-19. Br J Haematol. (2020) 190:e70-3. doi: 10.1111/bj h. 16860

91. Dimopoulos G, De Mast Q, Markou N, Theodorakopoulou M, Komnos A, Mouktaroudi M, et al. Favorable Anakinra responses in severe Covid-19 patients with secondary hemophagocytic lymphohistiocytosis. Cell Host Microbe. (2020) 28:117-23 el11. doi: 10.1016/j.chom.202 0.05 .007

92. Faguer S, Del Bello A, Abravanel F, Nicolau-Travers ML, Kamar N. Tocilizumab for hemophagocytic syndrome in a kidney transplant recipient with COVID-19. Ann Intern Med. (2020) 173:501-3. doi: 10.7326/L20-0419

93. Hakim NN, Chi J, Olazagasti C, Liu JM. Secondary hemophagocytic lymphohistiocytosis versus cytokine release syndrome in severe COVID-19 patients. Exp Biol Med (Maywood). (2021) 246:5-9. 1535370220962043. doi: 10.1177/1535370220962043

94. Wood H, Jones JR, Hui K, Mare T, Pirani T, Galloway J, et al. Secondary HLH is uncommon in severe COVID-19. Br J Haematol. (2020) 190:e2835. doi: 10.1111/bjh.16934

95. Chen W, Li Z, Yang B, Wang P, Zhou Q, Zhang Z, et al. Delayed-phase thrombocytopenia in patients with coronavirus disease 2019 (COVID-19). Br J Haematol. (2020) 190:179-84. doi: 10.1111/bjh.16885

96. Artru F, Alberio L, Moradpour D, Stalder G. Acute immune thrombocytopaenic purpura in a patient with COVID19 and decompensated cirrhosis. BMJ Case Rep. (2020) 13:e236815. doi: 10.1136/bcr-2020-236815

97. Bennett J, Brown C, Rouse $M$, Hoffmann $M$, Ye Z. Immune thrombocytopenia purpura secondary to COVID-19. Cureus. (2020) 12:e9083. doi: 10.7759/cureus.9083

98. Bomhof G, Mutsaers P, Leebeek FWG, Te Boekhorst PaW, Hofland J, Croles FN, et al. COVID-19-associated immune thrombocytopenia. Br J Haematol. (2020) 190:e61-4. doi: 10.1111/bjh.16850

99. Deruelle E, Ben Hadj Salem O, Sep Hieng S, Pichereau C, Outin H, Jamme M. Immune thrombocytopenia in a patient with COVID19. Int $J$ Hematol. (2020) 112:883-8. doi: 10.1007/s12185-02002943-5

100. Hindilerden F, Yonal-Hindilerden I, Sevtap S, Kart-Yasar K. Immune thrombocytopenia in a very elderly patient with Covid-19. Front Med (Lausanne). (2020) 7:404. doi: 10.3389/fmed.2020.00404

101. Hu Z, Chen W, Liang W, Xu C, Sun W, Yi Y. Severe exacerbation of immune thrombocytopenia and COVID-19: the favorable response to corticosteroid-based therapy-a case report. Ann Hematol. (2020). doi: 10.1007/s00277-020-04070-x. [Epub ahead of print].

102. Humbert S, Razanamahery J, Payet-Revest C, Bouiller K, Chirouze C. COVID-19 as a cause of immune thrombocytopenia. Med Mal Infect. (2020) 50:459-60. doi: 10.1016/j.medmal.2020.05.003

103. Levesque V, Millaire E, Corsilli D, Rioux-Masse B, Carrier FM. Severe immune thrombocytopenic purpura in critical COVID-19. Int J Hematol. (2020) 112:746-50. doi: 10.1007/s12185-020-02931-9

104. Mahevas M, Moulis G, Andres E, Riviere E, Garzaro M, Crickx E, et al. Clinical characteristics, management and outcome of COVID-19-associated immune thrombocytopenia: a French multicentre series. $\mathrm{Br} J$ Haematol. (2020) 190:e224-9. doi: 10.1111/bjh.17024

105. Malik J, Javaid M, Majedi O, Ishaq U, Zahid T. Paying in blood: a case of thrombocytopenia in Covid-19. Cureus. (2020) 12:e9791. doi: 10.7759/cureus.9791

106. Martincic Z, Skopec B, Rener K, Mavric M, Vovko T, Jereb M, et al. Severe immune thrombocytopenia in a critically ill COVID-19 patient. Int J Infect Dis. (2020) 99:269-71. doi: 10.1016/j.ijid.2020.08.002

107. Murt A, Eskazan AE, Yilmaz U, Ozkan T, Ar MC. COVID-19 presenting with immune thrombocytopenia: a case report and review of the literature. J Med Virol. (2021) 93:43-5. doi: 10.1002/jmv.26138
108. Nesr G, Garnett C, Bailey C, Koshy R, Arami S. Immune thrombocytopenia flare with mild COVID-19 infection in pregnancy: a case report. $\mathrm{Br} \mathrm{J}$ Haematol. (2020) 190:e146-8. doi: 10.1111/bjh.16928

109. Pascolini S, Granito A, Muratori L, Lenzi M, Muratori P. Coronavirus disease associated immune thrombocytopenia: Causation or correlation? J Microbiol Immunol Infect. (2020). doi: 10.1016/j.jmii.2020.08.006. [Epub ahead of print].

110. Patel T, Stanton N, Gkikas I, Triantafyllopoulou DID. Severe thrombocytopaenia secondary to COVID-19. BMJ Case Rep. (2020) 13:e237645. doi: 10.1136/bcr-2020-237645

111. Revuz S, Vernier N, Saadi L, Campagne J, Poussing S, Maurier F. Immune thrombocytopenic purpura in patients with COVID-19. Eur J Case Rep Intern Med. (2020) 7:001751. doi: 10.12890/2020_001751

112. Sadr S, Seyedalinaghi S, Ghiasvand F, Hassan Nezhad M, Javadian $\mathrm{N}$, Hossienzade R, et al. Isolated severe thrombocytopenia in a patient with COVID-19: a case report. IDCases. (2020) 21:e00820. doi: 10.1016/j.idcr.2020.e00820

113. Zulfiqar AA, Lorenzo-Villalba N, Hassler $\mathrm{P}$, Andres E. Immune thrombocytopenic purpura in a patient with Covid-19. N Engl J Med. (2020) 382:e43. doi: 10.1056/NEJMc2010472

114. Algassim AA, Elghazaly AA, Alnahdi AS, Mohammed-Rahim OM, Alanazi AG, Aldhuwayhi NA, et al. Prognostic significance of hemoglobin level and autoimmune hemolytic anemia in SARS-CoV-2 infection. Ann Hematol. (2021) 100:37-43. doi: 10.1007/s00277-020-04256-3

115. Berzuini A, Bianco C, Paccapelo C, Bertolini F, Gregato G, Cattaneo A, et al. Red cell-bound antibodies and transfusion requirements in hospitalized patients with COVID-19. Blood. (2020) 136:766-8. doi: 10.1182/blood.2020006695

116. Patil NR, Herc ES, Girgis M. Cold agglutinin disease and autoimmune hemolytic anemia with pulmonary embolism as a presentation of COVID-19 infection. Hematol Oncol Stem Cell Ther. (2020). doi: 10.1016/j.hemonc.2020.06.005. [Epub ahead of print].

117. Maslov DV, Simenson V, Jain S, Badari A. COVID-19 and cold agglutinin hemolytic anemia. TH Open. (2020) 4:e175-7. doi: 10.1055/s-0040-1715791

118. Huscenot T, Galland J, Ouvrat M, Rossignol M, Mouly S, Sene D, et al. SARS-CoV-2-associated cold agglutinin disease: a report of two cases. Ann Hematol. (2020) 99:1943-4. doi: 10.1007/s00277-020-04129-9

119. Zagorski E, Pawar T, Rahimian S, Forman D. Cold agglutinin autoimmune haemolytic anaemia associated with novel coronavirus (COVID-19). Br J Haematol. (2020) 190:e183-4. doi: 10.1111/bjh.16892

120. Hindilerden F, Yonal-Hindilerden I, Akar E, Yesilbag Z, Kart-Yasar K. Severe autoimmune hemolytic anemia in COVID-19 infection, safely treated with steroids. Mediterr J Hematol Infect Dis. (2020) 12:e2020053. doi: 10.4084/MJHID.2020.053

121. Capes A, Bailly S, Hantson P, Gerard L, Laterre PF. COVID-19 infection associated with autoimmune hemolytic anemia. Ann Hematol. (2020) 99:1679-80. doi: 10.1007/s00277-020-04137-9

122. Lazarian G, Quinquenel A, Bellal M, Siavellis J, Jacquy C, Re D, et al. Autoimmune haemolytic anaemia associated with COVID-19 infection. $\mathrm{Br}$ J Haematol. (2020) 190:29-31. doi: 10.1111/bjh.16794

123. Li M, Nguyen CB, Yeung Z, Sanchez K, Rosen D, Bushan S. Evans syndrome in a patient with COVID-19. Br J Haematol. (2020) 190:e5961. doi: $10.1111 /$ bjh.16846

124. Hindilerden F, Yonal-Hindilerden I, Akar E, Kart-Yasar K. Covid-19 associated autoimmune thrombotic thrombocytopenic purpura: report of a case. Thromb Res. (2020) 195:136-8. doi: 10.1016/j.thromres.2020.07.005

125. Albiol N, Awol R, Martino R. Autoimmune thrombotic thrombocytopenic purpura (TTP) associated with COVID-19. Ann Hematol. (2020) 99:16734. doi: 10.1007/s00277-020-04097-0

126. Franchini M, Glingani C, De Donno G, Casari S, Caruso B, Terenziani I, et al. The first case of acquired hemophilia A associated with SARS-CoV-2 infection. Am J Hematol. (2020) 95:E197-8. doi: 10.1002/ajh.25865

127. Battesti G, El Khalifa J, Abdelhedi N, Ferre V, Bouscarat F, Picard-Dahan C, et al. New insights in COVID-19-associated chilblains: a comparative study with chilblain lupus erythematosus. J Am Acad Dermatol. (2020) 83:1219-22. doi: 10.1016/j.jaad.2020.06.1018

128. Herman A, Peeters C, Verroken A, Tromme I, Tennstedt D, Marot L, et al. Evaluation of chilblains as a manifestation of 
the COVID-19 pandemic. JAMA Dermatol. (2020) 156:9981003. doi: 10.1001 /jamadermatol.2020.2368

129. Kanitakis J, Lesort C, Danset M, Jullien D. Chilblain-like acral lesions during the COVID-19 pandemic ("COVID toes"): histologic, immunofluorescence, and immunohistochemical study of 17 cases. J Am Acad Dermatol. (2020) 83:870-5. doi: 10.1016/j.jaad.2020.05.145

130. Cordoro KM, Reynolds SD, Wattier R, Mccalmont TH. Clustered cases of acral perniosis: clinical features, histopathology, and relationship to COVID19. Pediatr Dermatol. (2020) 37:419-23. doi: 10.1111/pde.14227

131. Dominguez-Santas M, Diaz-Guimaraens B, Garcia Abellas P, MorenoGarcia Del Real C, Burgos-Blasco P, Suarez-Valle A. Cutaneous smallvessel vasculitis associated with novel 2019 coronavirus SARS-CoV-2 infection (COVID-19). J Eur Acad Dermatol Venereol. (2020) 34:e5367. doi: $10.1111 /$ jdv.16663

132. Caputo V, Schroeder J, Rongioletti F. A generalized purpuric eruption with histopathologic features of leucocytoclastic vasculitis in a patient severely ill with COVID-19. J Eur Acad Dermatol Venereol. (2020) 34:e57981. doi: $10.1111 /$ jdv.16737

133. Mayor-Ibarguren A, Feito-Rodriguez M, Quintana Castanedo L, Ruiz-Bravo E, Montero Vega D, Herranz-Pinto P. Cutaneous small vessel vasculitis secondary to COVID-19 infection: a case report. J Eur Acad Dermatol Venereol. (2020) 34:e541-2. doi: 10.1111/jdv.16670

134. Negrini S, Guadagno A, Greco M, Parodi A, Burlando M. An unusual case of bullous haemorrhagic vasculitis in a COVID-19 patient. J Eur Acad Dermatol Venereol. (2020) 34:e675-6. doi: 10.1111/jdv.16760

135. De Perosanz-Lobo D, Fernandez-Nieto D, Burgos-Blasco P, Selda-Enriquez G, Carretero I, Moreno C, et al. Urticarial vasculitis in COVID-19 infection: a vasculopathy-related symptom? J Eur Acad Dermatol Venereol. (2020) 34:e566-8. doi: 10.1111/jdv.16713

136. Nasiri S, Dadkhahfar S, Abasifar H, Mortazavi N, Gheisari M. Urticarial vasculitis in a COVID-19 recovered patient. Int J Dermatol. (2020) 59:12856. doi: 10.1111/ijd.15112

137. Tahir A, Sohail Z, Nasim B, Parmar NV. Widespread cutaneous small vessel vasculitis secondary to COVID-19 infection. Int J Dermatol. (2020) 59:1278-9. doi: 10.1111/ijd.15106

138. Verheyden M, Grosber M, Gutermuth J, Velkeniers B. Relapsing symmetric livedo reticularis in a patient with COVID-19 infection. J Eur Acad Dermatol Venereol. (2020) 34:e684-6. doi: 10.1111/jdv.16773

139. Ozaras R, Berk A, Ucar DH, Duman H, Kaya F, Mutlu H. Covid-19 and exacerbation of psoriasis. Dermatol Ther. (2020) 33:e13632. doi: 10.1111/dth.13632

140. Gananandan K, Sacks B, Ewing I. Guttate psoriasis secondary to COVID-19. BMJ Case Rep. (2020) 13:e237367. doi: 10.1136/bcr-2020-237367

141. De Stefano L, Rossi S, Montecucco C, Bugatti S. Transient monoarthritis and psoriatic skin lesions following COVID-19. Ann Rheum Dis. (2020). doi: 10.1136/annrheumdis-2020-218520. [Epub ahead of print].

142. Romero-Sanchez CM, Diaz-Maroto I, Fernandez-Diaz E, Sanchez-Larsen A, Layos-Romero A, Garcia-Garcia J, et al. Neurologic manifestations in hospitalized patients with COVID-19: the ALBACOVID registry. Neurology. (2020) 95:e1060-70. doi: 10.1212/WNL.0000000000009937

143. Foresti C, Servalli MC, Frigeni B, Rifino N, Storti B, Gritti P, et al. COVID-19 provoking Guillain-Barre syndrome: the Bergamo case series. Eur J Neurol. (2020). doi: 10.1111/ene.14549. [Epub ahead of print].

144. Rifino N, Censori B, Agazzi E, Alimonti D, Bonito V, Camera G, et al. Neurologic manifestations in 1760 COVID-19 patients admitted to Papa Giovanni XXIII Hospital, Bergamo, Italy. J Neurol. (2020). doi: 10.1007/s00415-020-10251-5. [Epub ahead of print].

145. Koh JS, De Silva DA, Quek AML, Chiew HJ, Tu TM, Seet CYH, et al. Neurology of COVID-19 in Singapore. J Neurol Sci. (2020) 418:117118. doi: 10.1016/j.jns.2020.117118

146. Dixon L, Coughlan C, Karunaratne K, Gorgoraptis N, Varley J, Husselbee $J$, et al. Immunosuppression for intracranial vasculitis associated with SARS-CoV-2: therapeutic implications for COVID19 cerebrovascular pathology. I Neurol Neurosurg Psychiatry. (2021) 92:103-4. doi: 10.1136/jnnp-2020-324291

147. Oliveira RMC, Santos DH, Olivetti BC, Takahashi JT. Bilateral trochlear nerve palsy due to cerebral vasculitis related to COVID-19 infection. Arq Neuropsiquiatr. (2020) 78:385-6. doi: 10.1590/0004-282X20200052
148. Palao M, Fernandez-Diaz E, Gracia-Gil J, Romero-Sanchez CM, DiazMaroto I, Segura T. Multiple sclerosis following SARS-CoV-2 infection. Mult Scler Relat Disord. (2020) 45:102377. doi: 10.1016/j.msard.2020.102377

149. Zhou S, Jones-Lopez EC, Soneji DJ, Azevedo CJ, Patel VR. Myelin oligodendrocyte glycoprotein antibody-associated optic neuritis and myelitis in COVID-19. J Neuroophthalmol. (2020) 40:398-402. doi: 10.1097/WNO.0000000000001049

150. Parrotta E, Kister I, Charvet L, Sammarco C, Saha V, Charlson RE, et al. COVID-19 outcomes in MS: observational study of early experience from NYU Multiple Sclerosis Comprehensive Care Center. Neurol Neuroimmunol Neuroinflamm. (2020) 7:e835. doi: 10.1212/NXI.0000000000 000835

151. Restivo DA, Centonze D, Alesina A, Marchese-Ragona R. Myasthenia gravis associated with SARS-CoV-2 infection. Ann Intern Med. (2020) 173:10278. doi: 10.7326/L20-0845

152. Camelo-Filho AE, Silva AMS, Estephan EP, Zambon AA, Mendonca RH, Souza PVS, et al. Myasthenia gravis and COVID-19: clinical characteristics and outcomes. Front Neurol. (2020) 11:1053. doi: 10.3389/fneur.202 0.01053

153. Anand P, Slama MCC, Kaku M, Ong C, Cervantes-Arslanian AM, Zhou L, et al. COVID-19 in patients with myasthenia gravis. Muscle Nerve. (2020) 62:254-8. doi: 10.1002/mus.26918

154. Huang $\mathrm{H}$, Zhang $\mathrm{M}$, Chen $\mathrm{C}$, Zhang $\mathrm{H}$, Wei $\mathrm{Y}$, Tian J, et al. Clinical characteristics of COVID-19 in patients with preexisting ILD: A retrospective study in a single center in Wuhan, China. J Med Virol. (2020) 92:2742-50. doi: 10.1002/jmv.26174

155. Xu Z, Shi L, Wang Y, Zhang J, Huang L, Zhang C, et al. Pathological findings of COVID-19 associated with acute respiratory distress syndrome. The Lancet Respiratory Medicine. (2020) 8:420-2. doi: 10.1016/s2213-2600(20)30076-X

156. Flikweert AW, Grootenboers M, Yick DCY, Du Mee AWF, Van Der Meer NJM, Rettig TCD, et al. Late histopathologic characteristics of critically ill COVID-19 patients: Different phenotypes without evidence of invasive aspergillosis, a case series. J Crit Care. (2020) 59:14955. doi: 10.1016/j.jcrc.2020.07.002

157. Hui DS, Joynt GM, Wong KT, Gomersall CD, Li TS, Antonio G, et al. Impact of severe acute respiratory syndrome (SARS) on pulmonary function, functional capacity and quality of life in a cohort of survivors. Thorax. (2005) 60:401-9. doi: 10.1136/thx.2004.030205

158. Shi H, Han X, Jiang N, Cao Y, Alwalid O, Gu J, et al. Radiological findings from 81 patients with COVID-19 pneumonia in Wuhan, China: a descriptive study. Lancet Infect Dis. (2020) 20:425-34. doi: 10.1016/S1473-3099(20)30086-4

159. Wang Y, Dong C, Hu Y, Li C, Ren Q, Zhang X, et al. Temporal Changes of CT Findings in 90 Patients with COVID-19 Pneumonia: A Longitudinal Study. Radiology. (2020) 296:E55-64. doi: 10.1148/radiol.2020200843

160. Mo X, Jian W, Su Z, Chen M, Peng H, Peng P, et al. Abnormal pulmonary function in COVID-19 patients at time of hospital discharge. Eur Respir J. (2020) 55:2001217. doi: 10.1183/13993003.01217-2020

161. Sheth JU, Narayanan R, Goyal J, Goyal V. Retinal vein occlusion in COVID-19: a novel entity. Indian J Ophthalmol. (2020) 68:22913. doi: 10.4103/ijo.IJO_2380_20

162. Moeinzadeh F, Dezfouli M, Naimi A, Shahidi S, Moradi H. Newly diagnosed glomerulonephritis during COVID-19 infection undergoing immunosuppression therapy, a case report. Iran J Kidney Dis. (2020) 14:239-42.

163. Kissling S, Rotman S, Gerber C, Halfon M, Lamoth F, Comte D, et al. Collapsing glomerulopathy in a COVID-19 patient. Kidney Int. (2020) 98:228-31. doi: 10.1016/j.kint.2020.04.006

164. Deshmukh S, Zhou XJ, Hiser W. Collapsing glomerulopathy in a patient of Indian descent in the setting of COVID-19. Ren Fail. (2020) 42:87780. doi: 10.1080/0886022X.2020.1811122

165. Prendecki M, Clarke C, Cairns T, Cook T, Roufosse C, Thomas D, et al. Antiglomerular basement membrane disease during the COVID-19 pandemic. Kidney Int. (2020) 98:780-1. doi: 10.1016/j.kint.2020.06.009

166. Calabrese E, Zorzi F, Monteleone G, Del Vecchio Blanco G. Onset of ulcerative colitis during SARS-CoV-2 infection. Dig Liver Dis. (2020) 52:1228-9. doi: 10.1016/j.dld.2020.06.003 
167. Guerra I, Algaba A, Jimenez L, Mar Aller M, Garza D, Bonillo D, et al. Incidence, clinical characteristics, and evolution of SARS-CoV-2 infection in patients with inflammatory bowel disease: a single-center study in Madrid, Spain. Inflamm Bowel Dis. (2021) 27:25-33. doi: 10.1093/ibd/izaa221

168. Bezzio C, Saibeni S. Severe Ibd Flares and Covid-19: expand the gastroenterology-surgery team to include an infectious disease specialist. Gastroenterology. (2020). doi: 10.1053/j.gastro.2020.05.082. [Epub ahead of print].

169. Brancatella A, Ricci D, Viola N, Sgrò D, Santini F, Latrofa F. Subacute thyroiditis after Sars-COV-2 infection. J Clin Endocrinol Metab. (2020) 105:2367-70. doi: 10.1210/clinem/dgaa276
Conflict of Interest: The authors declare that the research was conducted in the absence of any commercial or financial relationships that could be construed as a potential conflict of interest.

Copyright (c) 2021 Tang, Hsu and Chen. This is an open-access article distributed under the terms of the Creative Commons Attribution License (CC BY). The use, distribution or reproduction in other forums is permitted, provided the original author(s) and the copyright owner(s) are credited and that the original publication in this journal is cited, in accordance with accepted academic practice. No use, distribution or reproduction is permitted which does not comply with these terms. 